\title{
1 Isolation of lactoferrin and immunoglobulins from dairy whey by an \\ 2 electrodialysis with filtration membrane process
}

3 Qiuyue Wang, George Q. Chen, Sandra E. Kentish*

4 Department of Chemical and Biomolecular Engineering, The University of Melbourne,

5 Victoria 3010, Australia

6

*Corresponding author. Tel: +6138344 6682; Fax: +61 38344 6682; E-mail: sandraek@unimelb.edu.au (SandraE.Kentish).

Abstract:

Isolation of high value minor proteins such as lactoferrin and immunoglobulins from crude dairy streams is a major challenge for the dairy industry. Here we investigate an electrodialysis with filtration membrane (EDFM) approach to separate lactoferrin (LF) and immunoglobulins (Ig) from other dairy proteins. A polyvinyl alcohol (PVA) membrane is prepared using phase inversion in a coagulation bath with $80 \%$ ethanol to serve as the filtration membrane. A range of treatment times and two electric field strengths ( 38.5 and $77 \mathrm{~V} / \mathrm{cm}$ ) were then investigated within the electrical cell. The results show that the filtration membrane prepared in-house can offer strong rejection for LF and Ig while allowing a high flux of other proteins. The separation of LF and Ig from a simulated whey solution can be achieved. The use of a partially demineralised whey reduces protein loss, but there is a tradeoff between the energy consumption and the protein removal rate as the extent of this demineralisation is increased. 


\section{Introduction:}

23 The dairy industry generates large quantities of whey which contain many nutrients such as lactose, soluble proteins, minerals, lactic acid and fats [1]. Generally, $7-11 \%$ of the total solids of whey are proteins [2]. Considering the vast quantum of whey produced globally (over160 million tons per annum [3]), the recovery of these proteins not only can decrease the environmental problems associated with its disposal, but also produce bioactive ingredients of high economic value.

The isolation of major whey proteins such as $\alpha$-lactalbumin ( $\alpha$-LA) and $\beta$-lactoglobulin ( $\beta$-LG) have been achieved[4] while the separation of minor whey proteins with similar size still need a satisfactory solution. The traditional method for whey protein extraction is chromatography, but it has disadvantages of fouling, long cycle times and high cost[5]. Further, chromatography adds significant volumes of salt to the factory effluent during the elution cycle, which is increasingly an issue for factories in rural regions where dryland salinity is increasing. Comparing with a chromatographic method, pressuredriven membrane filtration can be more cost-effective, but it has low selectivity. To improve the selectivity of the filtration method, electrodialysis with filtration membrane (EDFM) has been proposed. The use of an electrical driving force allows the EDFM process to have greater selectivity than a pressure driven filtration method [6]. Further, the elimination of a pressure driving force minimises the compressive forces that lead to a highly impermeable and non-selective fouling cake as occurs in protein microfiltration $[7,8]$.

The use of an electrical driving force to separate proteins in combination with a filtration membrane was first suggested by the Gradipore company [9], who showed that the approach could be used to separate Immunoglobulin $\mathrm{G}$ from human plasma[10], proteins from egg white [11] and haemoglobin from a mixture with bovine serum albumin [12]. Due to the relatively large size of the proteins the electrical field strength required to move the proteins across this membrane is high $(10 \mathrm{~V} / \mathrm{cm}$ to 2,000 $\mathrm{V} / \mathrm{cm}[10])$. This means that non-charged membranes must be used to prevent water splitting. The Gradipore company used polyacrylamide membranes for this purpose. However, these membranes are difficult to produce at a commercial scale, due to the use of toxic monomers and comonomers and the need to operate in oxygen-free conditions.

A similar approach, termed electrodialysis with ultrafiltration (EDUF) was later patented by the Bazinet group [13] for the separation of peptides. The smaller size of these molecules means that a lower electrical field strength can be used $(<15 \mathrm{~V} / \mathrm{cm})$. This lower field strength allows the use of charged ion exchange membranes to isolate the electrode chambers without water splitting. The Bazinet group have applied this technology to the separation of a range of molecules, including chitosan oligomers [14, 15], polyphenols[16], catechins[17]and anthocyanins [18]. 
Lactoferrin (LF) is a well-characterized iron-binding glycoprotein that belongs to the transferrin family [19]. It is a major whey protein in human milk with concentrations of $1.4-2.0 \mathrm{mg} / \mathrm{mL}$ but only a minor component in bovine milk with concentrations of only about $0.1-0.2 \mathrm{mg} / \mathrm{mL}$ [20]. Hence it is necessary to use highly concentrated, purified bovine LF as an ingredient of infant nutritional formula. Lactoferrin is an important antimicrobial milk protein [21]; and also has many other advantages for human health, such as antibacterial [22], antitumor [23] and anti-inflammation activity [24]. The immunoglobulins (Ig) are the largest protein in whey and comprise at least $2 \%$ of the total milk protein. They link various parts of the cellular and humoral immune system and prevent the adhesion of microbes, inhibit bacterial metabolism, agglutinate bacteria, augment phagocytosis of bacteria and neutralize toxins and viruses [25]. The nutritional, therapeutic, and functional characteristics of LF and Ig make the fractionation of LF and Ig of considerable commercial interest. However, the large-scale utilisation of LF requires a cost-effective purification process. The biggest challenge of Ig and LF fractionation is the separation of BSA and LF as they have similar size [26] and hence this is the focus of the present work.

Lactoferrin has a higher isoelectric point $(\sim 9)$ than other whey proteins $(\sim 5)$ in pure water and low salt solution concentrations [27], meaning that it is positively charged. However, when the ionic strength exceeds $30 \mathrm{mM}$ at $\mathrm{pH} 6.5$, negative values of the zeta potential are recorded[27]. This can be attributed to the formation of net-negatively charged LF aggregates or micelles, which are observed to form at $\mathrm{NaCl}$ concentrations above $10 \mathrm{mM}$ [27]. Mela et al.[27] observe that $60 \%$ of the dynamic light scattering intensity of LF can be attributed to large aggregates of $110 \mathrm{~nm}$ in size at $100 \mathrm{mM}$ salt concentration. It has also been reported that lactoferrin undergoes polymerisation in solutions of $10 \mathrm{mM}$ calcium chloride, with the predominant species being a tetramer of molecular weight $\sim 300 \mathrm{kDa}$ [28]. The ionic strength of either milk or whey is higher than $30 \mathrm{mM}$ and there is usually sodium and calcium present [29], so the net charge of lactoferrin particles in whey or milk is expected to be negative. This makes it hard to separate lactoferrin from other negatively charged proteins such as BSA based on charge. Ndiaye et al. [30] was able to transfer LF within an LF-enriched whey solution at $\mathrm{pH} 3.0$ from the feed to permeate channel of an EDUF unit separated by a polyethersulfone ultrafiltration membrane (MWCO: $500 \mathrm{kDa}$ ). However, the migration yield was only 15\% and the selectivity was decreased due to concomitant migration of $\beta$-lactoglobulin or other whey proteins.

Conversely, the aggregation of LF may make it possible to separate this molecule based on size. A membrane with a pore size larger than proteins such as BSA (molecular weight (MW): $\sim 66 \mathrm{kDa}$ ), while smaller than Ig (MW: 150 250 kDa) and tetramers of LF (MW: $312 \mathrm{kDa}$ ) can be used as the separation membrane in an EDFM system. A protein fraction rich in Ig and tetramers or aggregates of LF would then be obtained in the retentate chamber, which would be of great economic benefit. 
89 Poly (vinyl) alcohol (PVA) is selected in this work for the fabrication of a suitable ultrafiltration 90 separation membrane[31]. PVA is a nontoxic polymer with good chemical, thermal and mechanical 91 stability [32]. It is hydrophilic and known to be resistant to protein fouling [33-35]. The pore size of 92 the PVA filtration membrane can be controlled by varying the composition of polymer solution [36] 93 and coagulant bath during phase inversion [37]. However, PVA has very poor stability in aqueous 94 solutions, which makes it impossible to use directly for a membrane that will be used in the aqueous 95 phase [38]. Katz [39] and Senturk [40] treated PVA membranes using a heating method to improve 96 their water resistance and found that the application of heat decreased the water content of the 97 membrane, in turn reducing both the water and salt permeabilities and collapsing the pore structure. 98 Chemical crosslinking is a more common approach with dialdehydes such as glutaraldehyde [41] and 99 formaldehyde [42] generally used as the crosslinking agents.

100 In the present work, the aggregation of LF has been utilized to separate it from other proteins such as 101 BSA. PVA membranes are prepared by a phase inversion method to provide size selectivity between 102 LF and BSA. The water resistance of these membranes is increased by using glutaraldehyde as a 103 crosslinking agent, catalysed by sulfuric acid. To achieve a highly efficient, low investment and eco-

104 friendly approach to Ig and LF fractionation, the operating conditions of the EDFM process with these 105 in-house developed filtration membranes is then optimized. 


\section{Materials and Methods}

\subsection{Materials}

Poly vinyl alcohol (PVA, 89 kDa, 99+\% hydrolyzed) was purchased from Sigma (St. Louis, USA); the crosslinking reagent glutaric dialdehyde (25\%), solvents acetone (Purity $\geq 99.5 \%)$ and acetonitrile (HPLC grade) were purchased from Merck Pty Ltd (Darmstadt, Germany); other solvents such as methanol (99.5\%) and ethanol (99.5\%) were obtained from Chem-supply (Adelaide, Australia).

Experiments were performed using bovine serum albumin (BSA) with a purity greater than $98 \%$ (Sigma, St. Louis, USA) and lactoferrin (LF) concentrate with a LF concentration higher than 85\% which was kindly supplied by a Victorian dairy company. In real whey, the concentration of BSA and $\mathrm{LF}$ are around $0.4 \mathrm{~g} / \mathrm{L}$ and $0.1 \mathrm{~g} / \mathrm{L}$ respectively $[2,31]$. In these experiments, we elected to at least double these concentrations to ensure that these proteins could be adequately detected using High Performance Liquid Chromatography (HPLC).

An unflavoured whey protein isolate (WPI) powder (whey protein=91\%) branded as Bodies (NSW, Australia) was purchased from Chemist Warehouse (Melbourne, Australia). BSA (assay $\geq 98 \%$ ), LF (assay $\geq 85 \%$ ), Immunoglobulins (assay $\geq 99 \%$ ), $\beta$-lactoglobulin (assay $\geq 90 \%$ ) and $\alpha$-lactalbumin (assay $\geq 85 \%$ ) obtained from Sigma (St. Louis, USA) were used as standards for quantitative analysis of the corresponding protein through High Performance Liquid Chromatography (HPLC).

Simulated milk ultrafiltrate (SMUF) was used to represent the buffered salt mixture present in dairy whey. It was prepared according to Jenness(1962) [29] (see Supporting Information Table S1), in which potassium carbonate $(99 \%)$, potassium chloride (99\%), ethylenediaminetetraacetic acid (EDTA) disodium salt ( $>99 \%$ ), magnesium chloride ( $>98 \%$ ) and calcium chloride $(>99 \%)$ were purchased from Chem-supply (Adelaide, Australia); tri-sodium citrate (99\%), potassium dihydrogen orthophosphate (99\%-101\%), potassium hydroxide (99\%) and potassium sulphate (99\%) were obtained from Ajax Finechem (NSW, Australia); potassium citrate tribasic (assay $\geq 99 \%$ ) was purchased from Sigma (St. Louis, USA). In some cases, the divalent cationic salts (calcium and magnesium chloride) were excluded from this mixture, to evaluate their impact on the process and to reduce the possibility of mineral fouling.

Tris-base buffer was used in preliminary experiments to optimise the coagulation bath conditions for the membrane preparation. This was prepared from $20 \mathrm{mM}$ of Trizma ${ }^{\circledR}$ base (99.9\%) purchased from Sigma (St. Louis, USA) and $10 \mathrm{mM}$ of Hepes (99.8\%) purchased from Formedium Ltd (Hunstanton, England). 
139 Laemmli Sample buffer, Native sample buffer, Tris/Glycine buffer and Tris/Glycine/SDS buffer for 140 Native-Page and SDS-Page were supplied by Bio-Rad Laboratories Pty. Ltd (NSW, Australia).

141 All reagents were used without any further purification.

\subsection{Preparation of PVA filtration membranes}

To prepare the PVA solution, $44.5 \mathrm{~g}$ high-purity water $\left(18.2 \mathrm{M} \Omega \cdot \mathrm{cm}, 25^{\circ} \mathrm{C}\right)$ was added to a round bottom flask which was placed in a thermostatic oil bath $\left(90^{\circ} \mathrm{C}\right)$ and stirred under reflux. Then $5.5 \mathrm{~g}$ PVA was added into the water. The slurry was stirred at $90^{\circ} \mathrm{C}$ until no undissolved gel was observed, forming a viscous solution. The solution was then stirred for an additional $30 \mathrm{~min}$ under reflux to ensure complete dissolution of the PVA, then held overnight without stirring to remove entrained bubbles.

The PVA solution was cast onto a glass plate $(130 \mu \mathrm{m})$, air-dried for 5 minutes, and then immersed in a non-solvent coagulation bath $(300 \mathrm{~mL})$, containing a mixture of water and ethanol in a specific ratio, for 2 hours. Following this, the solvent was exchanged by immersion of the membranes in an acetone bath $(100 \mathrm{~mL})$ for 30 minutes to reduce membrane shrinkage and pore collapse upon drying. The membranes were air-dried overnight then annealed at $110^{\circ} \mathrm{C}$ for $1 \mathrm{hr}$.

After the annealing step, the membrane was put in $300 \mathrm{~mL}$ of high-purity water for $24 \mathrm{hr}$. To crosslink the membrane and so to improve its hot water resistance, the membrane was then placed in a crosslinking solution of $0.5 \% \mathrm{H}_{2} \mathrm{SO}_{4}$ and $1 \%$ glutaraldehyde for 20 min after wiping the water on its surface gently (Kimtech wipes). After crosslinking, the membrane was washed and put into $300 \mathrm{~mL}$ of high-purity $\mathrm{H}_{2} \mathrm{O}$ for at least 24 hours to eliminate any possible glutaraldehyde and sulfuric acid residuals. Each membrane was then immersed in the same buffer as the feed solution for at least 24 hours before each experiment.

\subsection{Analysis}

Cryo- Scanning electron microscopy (Cryo-SEM) images of PVA filtration membranes were taken with a Joel JSM-7001F scanning electron microscope.

A HPLC system with a Yarra ${ }^{\mathrm{TM}}$ Column $(3 \mu \mathrm{m}$ SEC-2000 $(300 \times 7.8 \mathrm{~mm}))$ from Phenomenex was used to determine the concentration of BSA, Ig, $\alpha$-LA and $\beta$-LG. Based on the column specifications, the mobile phase was a $0.1 \mathrm{M}$ phosphate buffer at a $\mathrm{pH}$ of 6.8 , with protein concentration evaluated at $220 \mathrm{~nm}$ using a UV detector. The injection volume was $10 \mu \mathrm{L}$ and the flowrate was $1 \mathrm{~mL} / \mathrm{min}$.

LF quantification is based on the method of Bobe et al [43]. A HPLC system with a C18 column (Jupiter $300 \AA$ C18) with Solvent A as 100 parts acetonitrile, 900 parts water and 1 part trifluoroacetic acid by volume; and Solvent B as 900 parts acetonitrile, 100 parts water and 1 part trifluoroacetic acid 
by volume was used. Keeping the column temperature at $45^{\circ} \mathrm{C}$ and sample temperature at $15{ }^{\circ} \mathrm{C}$. The

171 flow rate was $1 \mathrm{~mL} / \mathrm{min}$ and the gradient used was 0-2 $\mathrm{min}, 27 \%-34 \% \mathrm{~B}$; $2-18 \mathrm{~min}, 34 \%-37 \% \mathrm{~B}$; 18 -

$17223 \mathrm{~min}, 37 \% \mathrm{~B} ; 23-30 \mathrm{~min}, 37 \%-50 \% \mathrm{~B}$; 30-40 min, 50\%-55\% B; $40-45 \mathrm{~min}, 55 \%-27 \% \mathrm{~B}$.

173 Protein physicochemical properties were tested with a Malvern Zetasizer Nano ZS with phase analysis light scattering (PALS). The isoelectric points and mobilities of LF and BSA in pure water and

175 SMUF were determined by PALS, in which the $\mathrm{pH}$ titration was performed using $0.1 \mathrm{M} \mathrm{KOH}$ and 0.1

$176 \mathrm{M} \mathrm{HCl}$ solution.

177 SDS-PAGE and Native-PAGE were used to test the size of protein in a denatured state or native 178 state respectively. A Criterion ${ }^{\mathrm{TM}}$ cell from Bio-Rad Laboratories Pty., Ltd (NSW, Australia) with 179 specific running buffer, sample buffer, gel and sample preparation method was used. The operation 180 details of SDS-PAGE and Native-PAGE are shown in the Supporting information.

\subsection{EDFM module and running conditions}

All the EDFM tests are performed on a Gradipore Gradflow BF400 System kindly provided by Memphasys Limited (Sydney, Australia). As shown in Figure 1, the EDFM configuration is composed of one separation membrane, two restriction membranes and a pair of electrodes. The feed solution passes on one side of the membrane, with a buffer solution passing on the permeate side. Restriction membranes are used to allow the passage of ions to conduct the electric current, while preventing the proteins from entering into the electrode compartments. The restriction membranes used here are polyacrylamide (PAm) membranes with MWCO of $5 \mathrm{kDa}$ supplied by Memphasys Limited (Sydney,

190 Australia), or Neosepta cation-exchange membranes (CMB) and anion-exchange membranes (AHA) from Astom Corporation (Tokyo, Japan). The filtration membrane was a PVA membrane prepared inhouse as above. All membranes have an active area of $15.6 \mathrm{~cm}^{2}$. Unless otherwise stated, the skin layer (Figure S3) of the membrane faced the feed side. A tank placed inside the BF400 and chilled with iced water was used to maintain the temperature of all solutions at $15 \pm 1{ }^{\circ} \mathrm{C}$. 


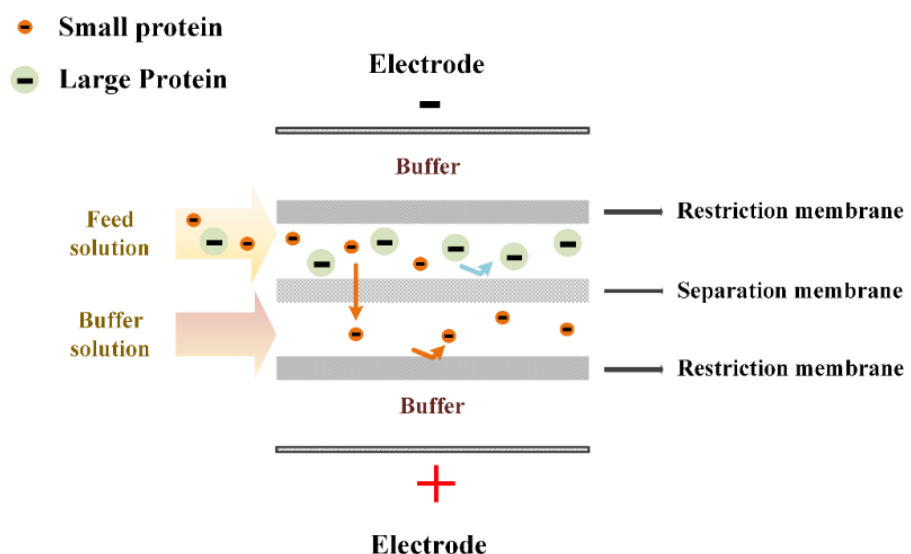

Figure 1 Schematic of an electrodialysis with filtration membrane (EDFM) approach to the separation of proteins from a feed solution.

The electrode solution used in EDUF processes is commonly sodium sulphate [44-46] or sodium chloride[30], replicating the common practice in conventional ED processes. However, in the present case, the electrode solution was prepared from an identical buffer to that of the feed and permeate solution (i.e. either SMUF, SMUF without divalent cations or TRIS-HEPES). This ensures that the feed whey solution is not contaminated with foreign ions such as sulphate due to ion transfer between the feed and electrode chambers, minimises Fickian diffusion of ions and ensures that the $\mathrm{pH}$ value of the EDFM system remains stable. One litre of buffer solution was placed in the electrode tank. This solution was continuously re-circulated at a flowrate of $3.4 \mathrm{~L} / \mathrm{min}$ through both electrode chambers throughout the experiment. Unless otherwise stated, the volume of permeate solution and feed solution was $10 \mathrm{~mL}$. These feed and permeate solutions were re-circulated through the membrane unit at a flowrate of 17 $\mathrm{mL} / \mathrm{min}$ each (crossflow velocity of $3.2 \mathrm{~cm} / \mathrm{s})$. A voltage of $100 \mathrm{~V}(\sim 77 \mathrm{~V} / \mathrm{cm}$, distance between two electrodes: $1.3 \pm 0.1 \mathrm{~cm}$ ) was applied for $30 \mathrm{~min}$ across the membrane stack unless otherwise stated.

\subsection{Calculation method}

After the determination of the target protein concentration by HPLC $[47,48]$, the flux $\left(F^{\prime}\right)$ of each specific protein can be defined as below:

$$
F^{\prime}=\frac{C_{P, t} \times V_{P, t}}{A \times \Delta t}
$$

where $\mathrm{C}_{\mathrm{P}, \mathrm{t}}$ is the protein concentration in the permeate, $V_{P, t}$ is the volume of the permeate solution at the end of EDFM process. A is the effective area of the separation membrane and $\Delta t$ is the treatment time.

The removal rate of a specific protein $\left(R^{\prime}\right)$ from the feed chamber can be defined as: 


$$
R^{\prime}=\frac{C_{F, 0} \times V_{F, 0}-C_{F, t} \times V_{F, t}}{A \times \Delta t}
$$

221

where $\mathrm{C}_{\mathrm{F}, 0}$ and $\mathrm{C}_{\mathrm{F}, \mathrm{t}}$ refers to the protein concentration in the feed at the beginning and at the end of EDFM process, $V_{F, 0}$ and $V_{F, t}$ are the volume of the feed solution at the beginning and at the end of EDFM process respectively.

The difference between the protein flux and the removal rate from the chamber represents the protein loss due to absorption on or within the membranes $\left(\mathrm{L}\right.$, in $\left.\mathrm{g} / \mathrm{m}^{2} . \mathrm{h}\right)$ during the EDFM process and so can be defined as below:

$$
L=F^{\prime}-R^{\prime}
$$

This total protein lost in this manner over the full experimental period $\left(\mathrm{P}, \mathrm{g} / \mathrm{m}^{2}\right)$ is:

$$
P=L . \Delta t
$$

Equation 4

While the percentage loss $(\% \mathrm{~L})$ is:

$$
\% L=\frac{L \cdot A \cdot \Delta t}{C_{F, 0} \times V_{F, 0}} \times 100 \%
$$

The water transfer or flux (F) during this process is defined as below:

$$
F=\frac{V_{P, t}-V_{P, 0}}{A \times \Delta t}
$$

The energy consumption $\mathrm{E}$ for removing BSA, $\alpha$-LA and $\beta$-LG from the retentate chamber can be calculated as below:

$$
\mathbf{E}=\frac{U \cdot \int I d t}{\left.m_{(B S A+\alpha-L A}+\beta-L G\right)}
$$

where $\mathrm{U}$ is the applied voltage $(\mathrm{V})$; I is the measured current $(\mathrm{A}) ; m_{(B S A+\alpha-\mathrm{LA}+\beta-\mathrm{LG})}(\mathrm{kg})$ is the total mass of BSA, $\alpha$-LA and $\beta$-LG removed from the feed chamber.

\subsection{Statistical Analysis}

A number of experiments were repeated in triplicate, to determine the percentage error in both flux and recovery, as two standard deviations either side of the mean. This percentage error was used to prepare error bars and error margins and to assess whether data was significantly different. 


\section{Results and discussion}

\subsection{The physicochemical properties of BSA and LF}

246 As aforementioned, the biggest challenge of Ig and LF fractionation is the separation of bovine serum 247 albumin (BSA) and lactoferrin as they have similar size. Proteins are quite sensitive to the solution 248 composition, so it is necessary to investigate the physicochemical properties as a function of this 249 composition.

250 A Native-PAGE analysis of a mixture of Ig (molecular weight: 150 250 kDa), LF (molecular weight: $\sim 78 \mathrm{kDa}$ ) and BSA (molecular weight: $66 \mathrm{kDa}$ ) made up in SMUF (no $\mathrm{Ca}^{2+}$ and $\mathrm{Mg}^{2+}$ ) indicated that the lactoferrin was unable to enter into the gel (Figure S1). This is quite different to the results of SDS-

253 PAGE, where surfactant was added to break down protein aggregates (see Figure S2). In this case, the 254 LF bands appear at the same molecular weight ( $\sim 78 \mathrm{kDa})$ as expected from the literature [27, 49]. As shown in Table S2, the mobility of LF in the Native-PAGE running buffer is also negative. This confirms that difference between Native-PAGE and SDS-PAGE is the aggregation of lactoferrin molecules to form tetramers (molecular weight $\sim 312 \mathrm{kDa}$ ) and aggregates in these solutions $[28,50]$.

Figure 2 shows the mobility of lactoferrin and BSA in different solutions, which again shows that the ions in the solution can affect the mobility of proteins. The isoelectric point of lactoferrin in pure water is consistent with the literature [30, 49, 51]; but both lactoferrin and BSA have a large change in their isoelectric point when dissolved in SMUF. As the composition of SMUF is close to that of whey, the isoelectric points shown in Figure 2 (6.2 for BSA and 5.2 for lactoferrin) are likely to be similar in a whey system. The similarity in these values makes it difficult to separate those two proteins based on their charge. 


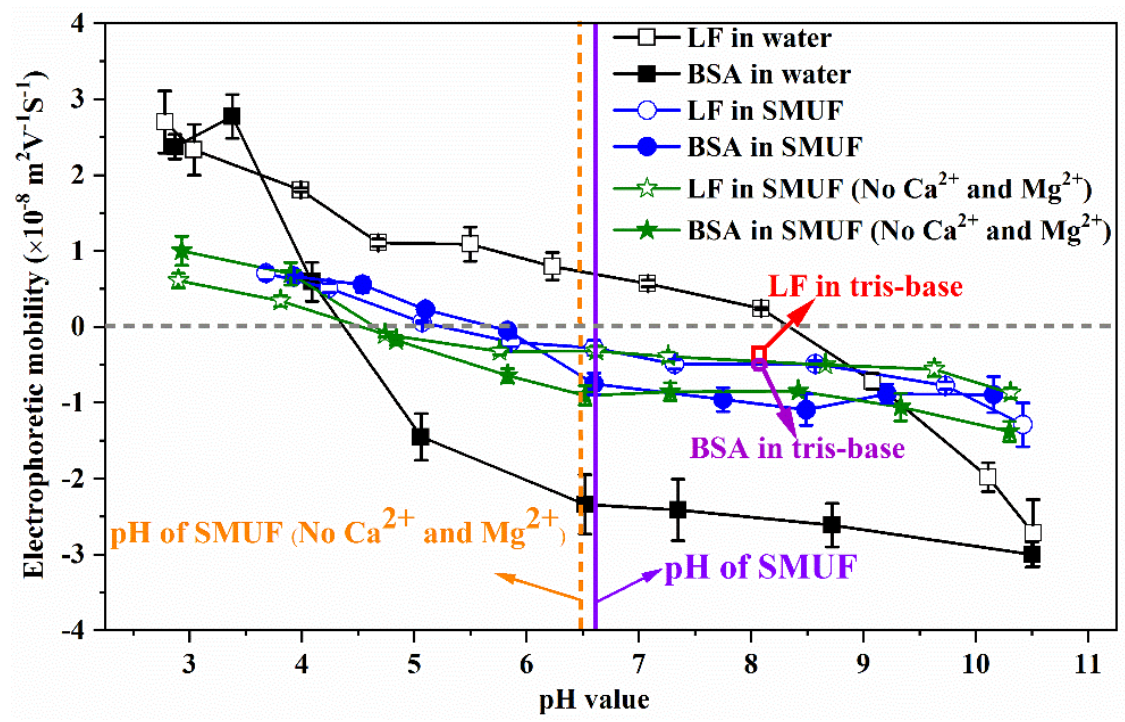

Figure 2 The electrophoretic mobility of lactoferrin (LF) and bovine serum albumin (BSA) in pure water and in simulated milk ultrafiltration permeate (SMUF), both with and without divalent cations.

The vertical dashed line shows the $\mathrm{pH}$ of the SMUF without the divalent cations, while the solid vertical line shows the $\mathrm{pH}$ when these are added. The horizontal dashed line shows the isoelectric point (red square: mobility of LF in tris-base buffer; purple circle: mobility of BSA in tris-base buffer) changing from 8.4 to 5.2 when SMUF buffer is used. Further tests showed that this buffer could be diluted up to 85 times before the electrophoretic mobility of LF changed from negative to positive (Figure 3a). This mobility may be affected by the $\mathrm{pH}$ change that also occurs during dilution, so separate tests with controlled $\mathrm{pH}(6.6)$ were also conducted (see Figure $3 \mathrm{~b}$ ). The addition of alkali ( $0.1 \mathrm{M} \mathrm{KOH})$ to control $\mathrm{pH}$ increases the conductivity of the diluted solution slightly, which in this case means that the lactoferrin remains negatively charged after dilution of 120 times. This confirms that the lactoferrin will remain negatively charged and aggregated even if an eightfold diluted SMUF is used and/or if there is significant water migration during the EDFM process. 

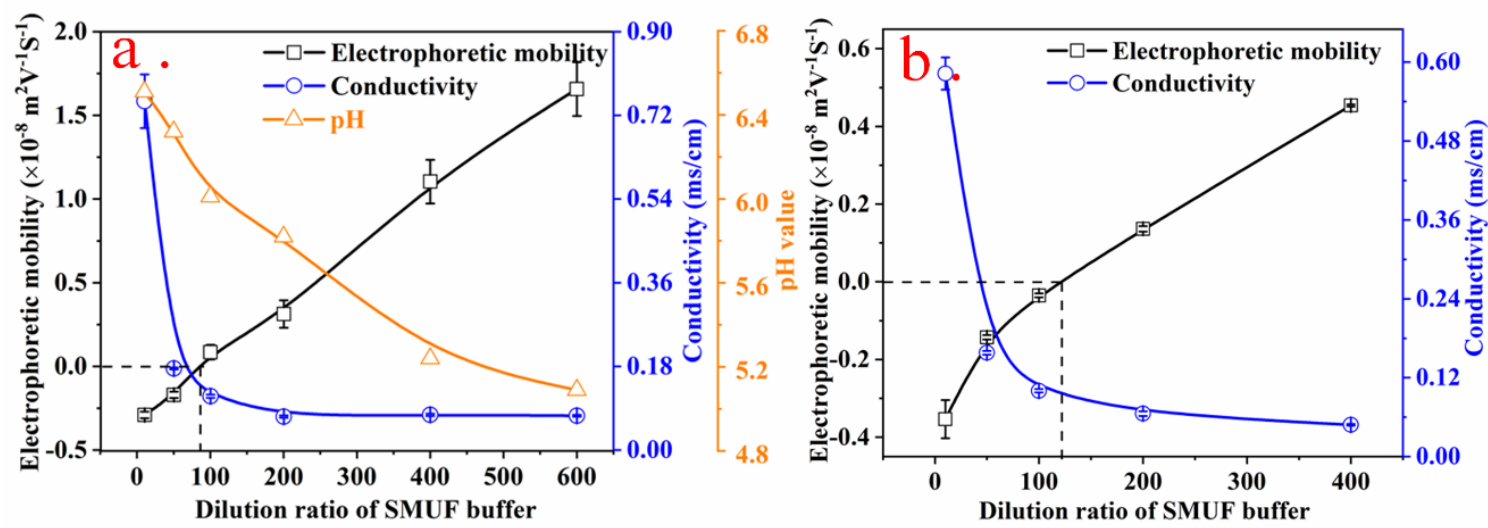

Figure 3 The conductivity of diluted SMUF and the mobility of lactoferrin $(1 \mathrm{~g} / \mathrm{L})$ in diluted SMUF (a. solutions diluted with water; b. solutions diluted with water, $\mathrm{pH}$ maintained at 6.6 using $0.1 \mathrm{M}$ $\mathrm{KOH})$.

Based on this mobility test, both BSA and lactoferrin are negatively charged in whey systems. Ig is also known to be negatively charged, with an isoelectric point of $\sim 5.0$ regardless of solution composition [2]. Under the influence of an appropriate electrical driving force, a membrane with molecular weight cut-off larger than BSA and smaller than Ig or a tetramer of LF would thus allow these two valuable proteins to be separated from smaller whey proteins.

\subsection{PVA filtration membrane characterization and optimization}

\subsubsection{Optimization of membrane structure}

To provide a non-fouling separation membrane of the appropriate pore size ( $150 \mathrm{kDa})$, PVA was used in a phase inversion process. The pore size and composition of these uncrosslinked membranes were optimised by varying the coagulation bath composition (see Supporting Information). These initial experiments concluded that a coagulation bath of 80 to $85 \mathrm{vol} \%$ ethanol in water achieved the best BSA flux and BSA/Ig selectivity. The addition of methanol into the bath increased the pore size and thus reduced the $\mathrm{BSA} / \mathrm{Ig}$ selectivity and so this addition was not considered further.

However, these uncrosslinked membranes could be dissolved in hot water even after annealing at 110 ${ }^{\circ} \mathrm{C}$ for 1 hour. This means that the membrane will not survive prolonged exposure to aqueous solutions even at lower temperatures. The use of thermal treatment to improve water resistance resulted in membranes of smaller pore size $[39,40]$. Hence, chemical crosslinking with $0.5 \% \mathrm{H}_{2} \mathrm{SO}_{4}$ and $1 \%$ glutaraldehyde was used as an alternative approach to strengthen the structures. After chemical crosslinking, a slightly greater BSA flux was achieved, but the increase was almost within the error margin, indicating that the crosslinking step had little influence on the membrane pore size (Table 1). 
LF and BSA. Further experiments confirmed that varying the ethanol concentration within the coagulation bath between 75 and $85 \%$ had little impact on these BSA and LF fluxes (see Supporting Information) and so a bath of $80 \mathrm{vol} \%$ ethanol was chosen for further study.

312 Table 1 The performance of membranes prepared with an $85 \mathrm{vol} \%$ ethanol coagulation bath, after annealing at $110^{\circ} \mathrm{C}$ for $1 \mathrm{~h}$; and after annealing at $110^{\circ} \mathrm{C}$ for $1 \mathrm{~h}$ followed by crosslinking with glutaraldehyde (feed solution: $10 \mathrm{~mL} 1 \mathrm{~g} / \mathrm{L} \mathrm{BSA}$, Tris-base buffer, $100 \mathrm{~V}(\sim 77 \mathrm{~V} / \mathrm{cm}), 30 \mathrm{~min})$

\begin{tabular}{ccccc}
\hline Membrane & $\begin{array}{c}\text { BSA concentration } \\
(\mathrm{g} / \mathrm{L})\end{array}$ & $\begin{array}{c}\text { BSA flux }\left(\mathrm{g} \cdot \mathrm{m}^{-}\right. \\
\left.{ }^{2} \cdot \mathrm{h}^{-1}\right)\end{array}$ & $\begin{array}{c}\text { BSA loss }\left(\mathrm{g} \cdot \mathrm{m}^{-}\right. \\
\left.{ }^{2} \cdot \mathrm{h}^{-1}\right)\end{array}$ & $\begin{array}{c}\text { Water Transfer } \\
\left(\mathrm{g} \cdot \mathrm{m}^{-2} \cdot \mathrm{h}^{-1}\right)\end{array}$ \\
\hline No crosslinking & 1 & $11.0 \pm 0.5$ & $2.9 \pm 0.4$ & $+0.6 \pm 0.2$ \\
Crosslinking & 1 & $13.2 \pm 0.5$ & $1.9 \pm 0.3$ & $+1.0 \pm 0.3$ \\
\hline
\end{tabular}

315 (water transfer: "+ " means water transfer from permeate chamber to feed chamber)

316 The zeta potential of the membranes after crosslinking is $-13 \pm 2 \mathrm{mV}$ ( $\mathrm{pH}=6.5$ ), so the crosslinking 317 induces a negative charge that is similar to that observed in commercial nanofiltration membranes[52].

318 This negative charge reduces the membrane fouling (BSA loss) relative to an uncrosslinked membrane, 319 due to repulsion of the negatively charged BSA from the charged membrane surface (see Table 1). 320 Secondly, under the same voltage, using a crosslinked membrane leads to a higher cell current density 321 than using a membrane with no crosslinking, due to the onset of some water splitting at the high voltages used (See Figure 4). While this will increase the energy requirement for the process somewhat, the water transfer does not increase significantly (Table 1), indicating that electro-osmotic flows should not be of concern.

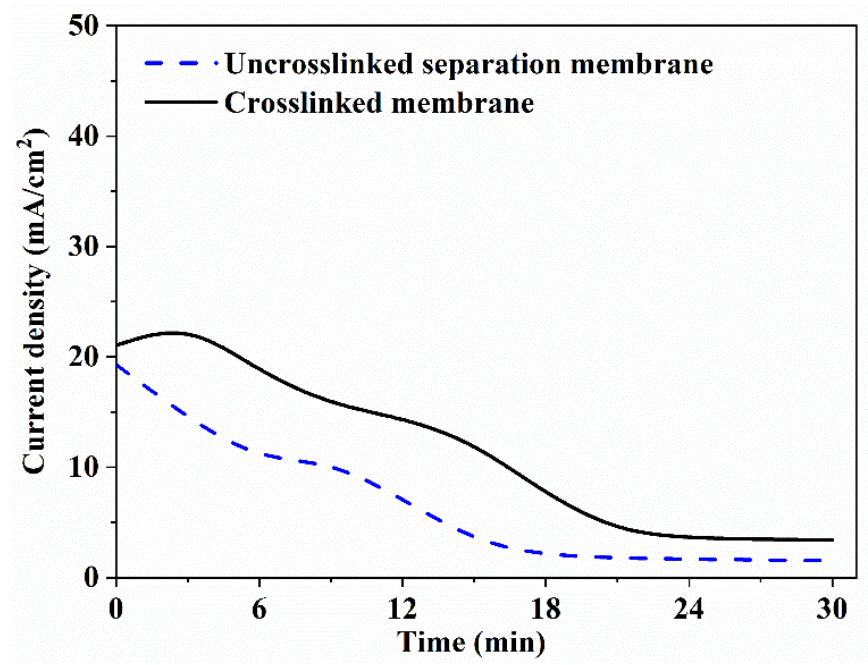

Figure 4 the current density of the system when using an uncrosslinked membrane and crosslinked membrane (coagulation bath: $80 \mathrm{vol} \%$ ethanol, Feed solution: $10 \mathrm{~mL} 1 \mathrm{~g} / \mathrm{L} \mathrm{LF}$, Tris-base, $\mathrm{pH}=8$, Voltage: $100 \mathrm{~V}(\sim 77 \mathrm{~V} / \mathrm{cm}), 30 \mathrm{~min})$ 


\subsection{Reduction of protein loss due to fouling}

To reduce the protein loss due to fouling and the energy intensity we reduced the ionic strength of the buffer, by using a diluted SMUF. The LF loss halves from $3.5 \mathrm{~g} \cdot \mathrm{m}^{-2} \cdot \mathrm{h}^{-1}$ (shown in Figure 5) to 1.4 $\mathrm{g} \cdot \mathrm{m}^{-2} \cdot \mathrm{h}^{-1}$ (Table 2) under these conditions. This may be because the lower ionic strength provides less screening of the protein and membrane charge (see Figure 3), so that repulsion between these is greater. Further, the absorbed lactoferrin can be readily desorbed when using a $0.5 \mathrm{M} \mathrm{NaCl}$ wash for $30 \mathrm{~min}$ (0.5/1 M NaCl, $\mathrm{pH} 7)$.

We also considered the use of ion exchange membranes as restriction membranes, as this is common in EDUF applications[13]. Our earlier work had also indicated that the use of such charged membranes could increase protein recovery by reducing the absorption of charged proteins[53]. When using cation-exchange membranes (CEM) for the restriction membranes, the loss of lactoferrin can be reduced to $0.2 \mathrm{~g} / \mathrm{m}^{2} . h r$ and again this can be recovered during a saltwater wash (Table 2). Conversely, the use of anion-exchange membranes (AEM) leads to a greater loss of $2.7 \mathrm{~g} / \mathrm{m}^{2} . \mathrm{hr}$. The positively charged surface of the AEM is attractive for deposition of the negatively charged lactoferrin molecules. Only around half of this absorbed lactoferrin can be desorbed when using a salty water wash.

Table 2 The recovery rate of LF when using different membranes as restriction membrane (Feed solution: $10 \mathrm{~mL} 1 \mathrm{~g} / \mathrm{L} \mathrm{LF}, 1 / 4$ SMUF no $\mathrm{Ca}^{2+}$ and $\mathrm{Mg}^{2+}$, voltage: $50 \mathrm{~V}(\sim 38 \mathrm{~V} / \mathrm{cm})$, time: $\left.30 \mathrm{~min}\right)$

\begin{tabular}{lcccc}
\hline & Membrane & PAm membrane & AEM & CEM \\
\hline LF flux & $\left(\mathrm{g} \cdot \mathrm{m}^{-2} \cdot \mathrm{h}^{-1}\right)$ & & & \\
LF loss & $\left(\mathrm{g} \cdot \mathrm{m}^{-2} \cdot \mathrm{h}^{-1}\right)$ & 0 & 0 & 0 \\
& $(\%)$ & $1.4 \pm 0.3$ & $2.7 \pm 0.6$ & $0.2 \pm 0.1$ \\
Wash condition $(0.5 \mathrm{~h})$ & $12 \pm 3$ & $24 \pm 6$ & $1.9 \pm 0.4$ \\
Recovered & $\left(\mathrm{g} \cdot \mathrm{m}^{-2} \cdot \mathrm{h}^{-1}\right)$ & $0.5 \mathrm{M} \mathrm{NaCl}$ & $0.5 \mathrm{M} \mathrm{NaCl}$ & $0.5 \mathrm{M} \mathrm{NaCl}$ \\
\multicolumn{2}{l}{ Water transfer $(\mathrm{g})$} & $1.9 \pm 0.4$ & $1.5 \pm 0.3$ & $0.4 \pm 0.1$ \\
\hline
\end{tabular}

(water transfer: "+ " means water transfer from permeate chamber to retentate chamber)

While not discussed in our prior work[53], the use of ion exchange membranes in place of the neutral PAm, is likely to also cause the onset of greater water splitting, which in turn will result in significantly greater energy demand and higher electro-osmotic flows of water. Indeed, the PAm membranes results in less water transfer than when ion exchange membranes are used (Table 2). 
The permselectivity of most commercial ion exchange membranes in dilute salt solutions is between 90 and $100 \%$ due to the presence of fixed charge groups[54]. Thus, the transport number of counter ions are 0.9 1 and co-ions have a transport number of 0 0.1. As shown by Długołęcki et al.[55], the limiting current density $\left(i_{l i m}\right)$ of a membrane can be calculated by Equation 8 :

$$
i_{l i m}=\frac{F \cdot C^{b} \cdot D}{\delta\left(t_{c o u}^{m}-t_{c o u}^{s}\right)}
$$

\section{Equation 8}

360

Where $\mathrm{F}$ is the Faraday constant, $\mathrm{D}$ is the salt diffusion coefficient, $C^{b}$ is the bulk solution concentration, $t_{c o u}^{m}$ and $t_{c o u}^{s}$ is the counter ion transport number in the membrane and solution respectively and $\delta$ is the boundary layer thickness. For ion exchange membranes at the salt solution concentrations in $1 / 4$ SMUF, the limiting current density is around $5-10 \mathrm{~mA} / \mathrm{cm}^{2}$ [55]. Conversely, as the PAm is a neutral hydrogel membrane with a very high water concentration, the values of $t_{c o u}^{m}$ and $t_{c o u}^{S}$ are essentially identical, so that the denominator in the equation above approaches zero and the limiting current approaches infinity. The utilization of these neutral membranes in the system thus makes it is possible to apply a higher voltage than other EDUF processes without water splitting [30, $56]$.

To further investigate the effects of water splitting, a mixture of BSA and LF was used with the different restriction membranes.

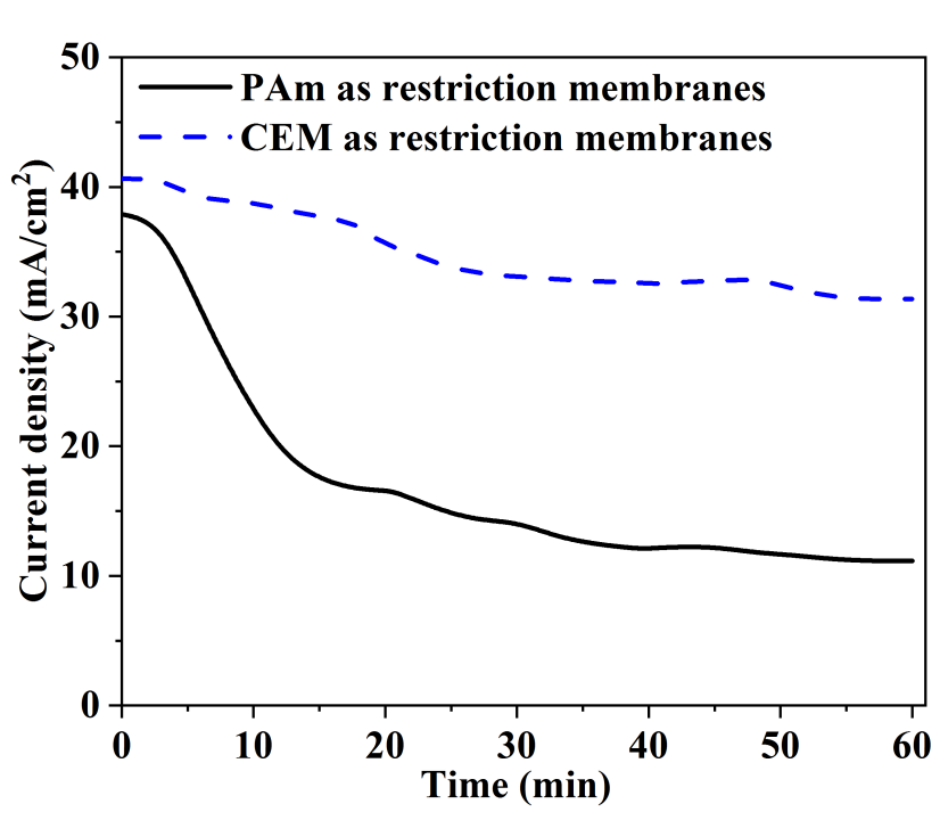

Figure 6 The current density for experiments with different restriction membranes treating a mixture of $0.8 \mathrm{~g} / \mathrm{L} \mathrm{BSA}$ and $0.2 \mathrm{~g} / \mathrm{L} \mathrm{LF}$ (feed solution: $40 \mathrm{~mL}, 1 / 4$ SMUF no $\mathrm{Ca}^{2+}$ and $\mathrm{Mg}^{2+}, \mathrm{pH}=8$, voltage: 50 $\mathrm{V}(\sim 38 \mathrm{~V} / \mathrm{cm})$, time: $40 \mathrm{~min})$. 
The current density of the system with CEMs as restriction membranes is clearly higher than when using the PAm membrane (Figure 6) and exceeds the limiting current density predicted from the literature[55]. Further, in this arrangement, the $\mathrm{pH}$ of both the retentate solution and permeate solutions increases substantially from 8.1 to 11.6 and 12.2 respectively (Table 3); at the same time, the pH of the electrode solution is reduced to 3.5. Further, the conductivity of the retentate and permeate solutions increase significantly. The high current density, changes in $\mathrm{pH}$ and conductivity all indicate that there is significant water splitting on the surface of the CEM [29, 55]. and that most of the current for the process has been used in water splitting and the resulting ion transfer, consuming energy .

The BSA flux obtained in repeat experiments using the CEM restriction membranes was highly variable. Contrary to our prior work[53], there also appeared to be no increase in this flux relative to the use of a PAm restriction membrane. The $\mathrm{pH}$ changes observed in our earlier work were much less significant, due to the use of an alternate buffer system. In the present case, the increase in $\mathrm{pH}$ above 11 , is likely to cause deprotonation of the tyrosine residues within BSA, resulting in significant denaturation and loss of secondary structure[60]. This denaturation could cause the BSA to aggregate, preventing permeation. The denaturation was evident during sample analysis, as the BSA could often not be detected using the size exclusion column and the retention time shifted when using a C18 column. Thus, while the use of CEMs may reduce the protein loss, it is not an economical or efficient approach.

Table 3 The $\mathrm{pH}$ value of each chamber after treating for 60 min when using different membranes (feed solution: $40 \mathrm{~mL} 0.8 \mathrm{~g} / \mathrm{L}+0.2 \mathrm{~g} / \mathrm{L} \mathrm{LF}$; $1 / 4$ SMUF no $\mathrm{Ca}^{2+}$ and $\mathrm{Mg}^{2+}, \mathrm{pH}=8$, voltage: $50 \mathrm{~V}$ ( 38 $\mathrm{V} / \mathrm{cm})$, time: $60 \mathrm{~min}$ )

\begin{tabular}{cccccccc}
\hline $\begin{array}{c}\text { Restriction } \\
\text { Membranes }\end{array}$ & Separation & \multicolumn{2}{c}{ Retentate solution } & \multicolumn{2}{c}{ Permeate solution } & \multicolumn{2}{c}{ Electrode solution } \\
& Membranes & $\mathrm{pH}$ & $\begin{array}{c}\text { Cond. } \\
(\mathrm{ms} / \mathrm{cm})\end{array}$ & $\mathrm{pH}$ & $\begin{array}{c}\text { Cond. } \\
(\mathrm{ms} / \mathrm{cm})\end{array}$ & $\mathrm{pH}$ & $\begin{array}{c}\text { Cond. } \\
(\mathrm{ms} / \mathrm{cm})\end{array}$ \\
\hline \multicolumn{2}{c}{ Initial value } & $8.1 \pm 0.4$ & $1.9 \pm 0.1$ & $8.1 \pm 0.4$ & $1.7 \pm 0.1$ & $8.1 \pm 0.4$ & $1.7 \pm 0.1$ \\
\multirow{2}{*}{ PAm } & Crosslinked & $7.6 \pm 0.5$ & $0.77 \pm 0.03$ & $7.9 \pm 0.6$ & $3.3 \pm 0.2$ & $8.2 \pm 0.6$ & $1.7 \pm 0.1$ \\
& PVA & & & & & & \\
\multirow{2}{*}{ PAm } & Uncrosslinked & $7.7 \pm 0.5$ & $0.94 \pm 0.05$ & $8.1 \pm 0.6$ & $3.1 \pm 0.2$ & $7.9 \pm 0.6$ & $2.0 \pm 0.2$ \\
& PVA & & & & & & \\
\multirow{2}{*}{ CEM } & Crosslinked & $11.6 \pm 0.1$ & $5.8 \pm 0.6$ & $12.2 \pm 0.1$ & $47 \pm 4$ & $3.5 \pm 0.1$ & $1.1 \pm 0.1$ \\
& PVA & & & & & & \\
\hline
\end{tabular}

The chemical crosslinking of the PVA separation membrane also results in this membrane gaining some charge. For this reason, the use of an uncrosslinked separation membrane was also tested under these conditions. As shown in Table 3, the change of $\mathrm{pH}$ and conductivity of each chamber is much smaller when the separation membrane is changed in this manner, indicating that water splitting is much 
less significant. A process with PAm restriction membranes and a crosslinked PVA separation membrane, coupled with a cleaning process to recover adsorbed protein appears to be the best option.

\subsection{Whey protein isolate (WPI) treatment}

The optimized process was then used in the treatment of a model whey system. This model whey was prepared from commercial whey protein isolate powder, which is free of salts. Feed solutions with a protein composition similar to that of whey were prepared by combining $6.5 \mathrm{~g} / \mathrm{L}$ WPI, $0.2 \mathrm{~g} / \mathrm{L} \mathrm{LF}, 0.4$ $\mathrm{g} / \mathrm{L}$ BSA, $0.5 \mathrm{~g} / \mathrm{L} \mathrm{Ig}$. The conductivity may affect the protein removal rate and protein loss of this process, so feed solutions with 4 times diluted SMUF $\left(\right.$ no $\mathrm{Ca}^{2+}$ and $\mathrm{Mg}^{2+}$ ) and 8 times diluted SMUF (no $\mathrm{Ca}^{2+}$ and $\mathrm{Mg}^{2+}$ ) at a $\mathrm{pH}$ of 8 were compared. These dilutions are indicative of partially demineralised and de-ionised whey, a common intermediate in dairy processing operations.

Owing to its lower electrical resistance, the process with 4 times diluted SMUF (no $\mathrm{Ca}^{2+}, \mathrm{Mg}^{2+}$ ) initially offers a higher protein removal rate than the process with 8 times diluted SMUF (no $\mathrm{Ca}^{2+}$, $\mathrm{Mg}^{2+}$ ) (see Figure 7). For this process, nearly half of the total protein in the feed solution has been moved to the permeate after 60 minutes of treatment. As the permeate solution is being recycled, at this point the concentration of protein in the permeate becomes higher than that in the feed solution. This results in a significant back diffusion of protein into the feed chamber due to Fick's Law, as also observed in conventional ED processes [61]. This dynamic balance between the electrical and diffusional driving forces means that the concentration of protein in both feed solutions begins to stabilise after 60 minutes of treatment and further treatment is ineffective. As shown in Figure S5-S7, the removal rate of individual proteins also shows the same trend, with $\alpha$-lactalbumin particularly affected due to its lower isoelectric point (4.5 4.8) and smaller molecular size (14.2 kDa) [2] compared with other whey proteins (Figure S5). In industrial practice, this issue would be overcome by increasing the permeate/feed volume ratio, or by avoiding a permeate recycle and instead using a continuous counter current operation. Conversely the protein transfer for the case with 1/8 SMUF was slower so in the timescale of this experiment it did not reach a dynamic balance. 

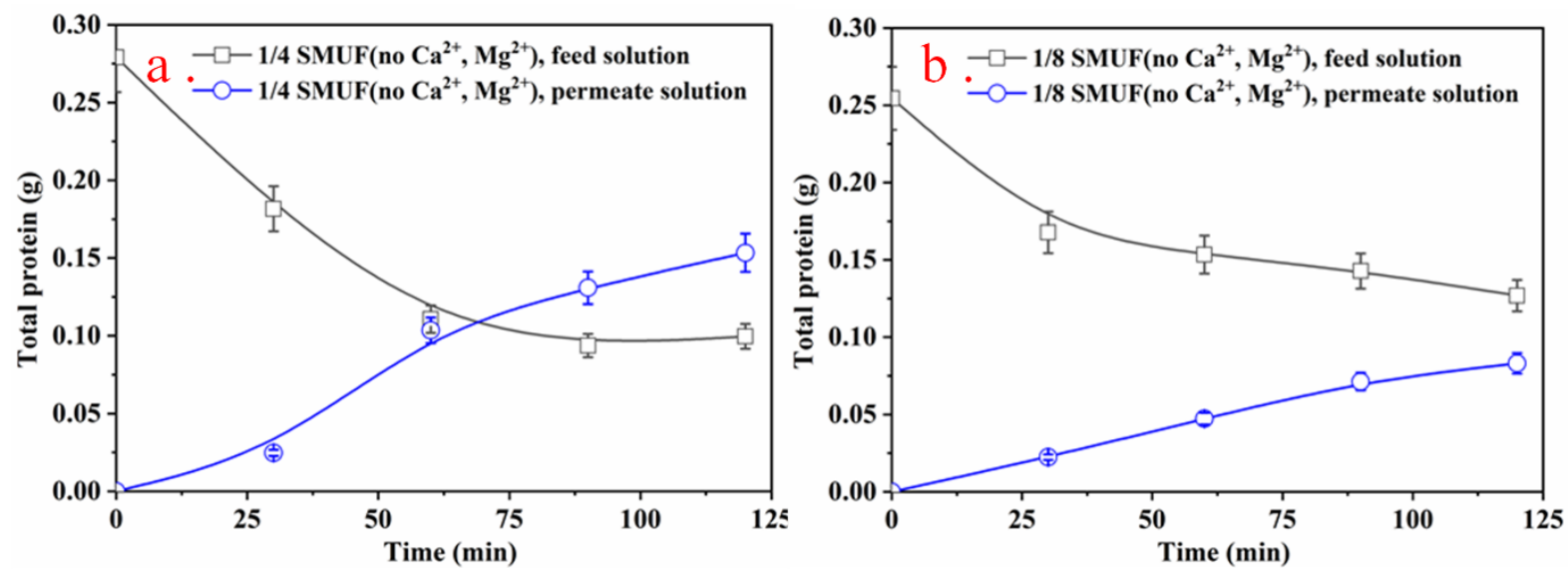

Figure 7 The amount of total protein $(\alpha-\mathrm{LA}+\beta-\mathrm{LG}+\mathrm{BSA})$ vs time in the feed/permeate chamber when using (a) 1/4 SMUF and (b) 1/8 SMUF as buffer solution (feed solution: $40 \mathrm{~mL}$ model whey solution prepared from WPI, $\mathrm{pH}=8$, voltage: $100 \mathrm{~V}(\sim 77 \mathrm{~V} / \mathrm{cm})$, time: $2 \mathrm{~h})$.

As shown in Figure 8, the process can realize the isolation of LF and Ig from BSA, $\alpha$-LA and $\beta$ $\mathrm{LG}$ in the period before this dynamic balance is reached, with the flux of $\beta$-LG over twenty times that of Ig. The protein composition of the retentate chamber shows the steady migration of the smaller proteins (BSA, $\alpha$-LA and $\beta$-LG) (see Figure 9) into the permeate, leading to an increasing proportion of LF/Ig in the retentate chamber. Given the small membrane area and the buildup of protein in the permeate solution, pure protein solutions cannot be obtained within the timescale of the experiment. However, it is anticipated that if permeate recycling is avoided and a larger membrane area is used that a retentate of pure Ig and LF can be obtained. 


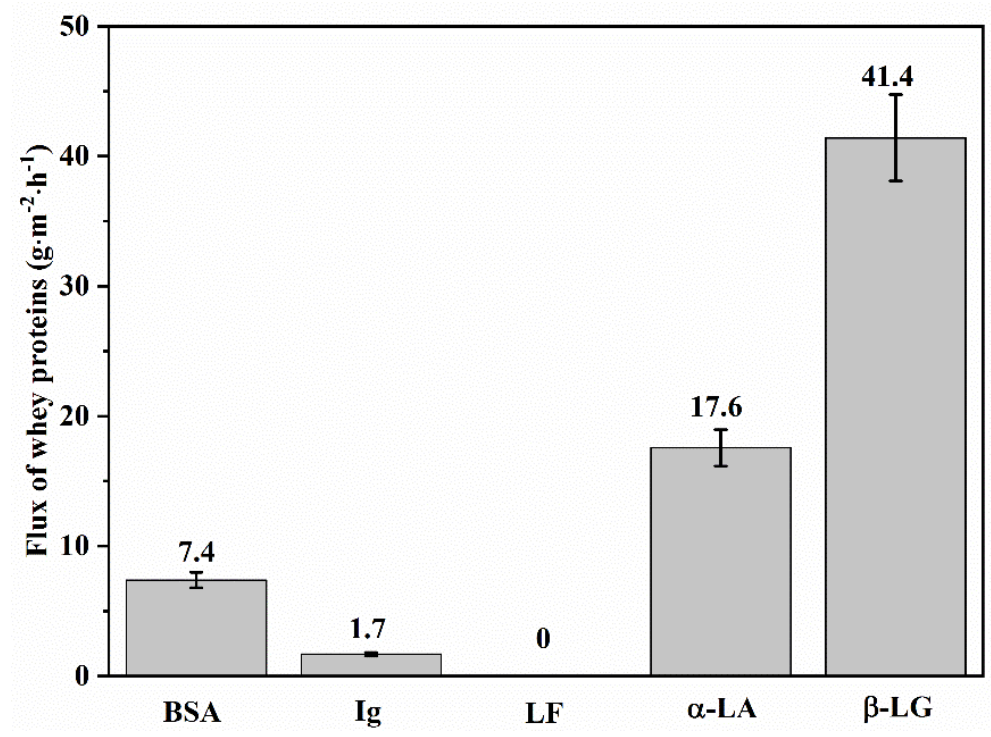

Figure 8 The flux of different whey proteins based on a 1-hour experiment using a model whey solution prepared from WPI (feed solution: $40 \mathrm{~mL}$ model whey solution prepared from WPI; 1/4 SMUF (no $\left.\mathrm{Ca}^{2+}, \mathrm{Mg}^{2+}\right) \mathrm{pH}=8$, voltage: $100 \mathrm{~V}(\sim 77 \mathrm{~V} / \mathrm{cm})$, time: $\left.1 \mathrm{~h}\right)$.

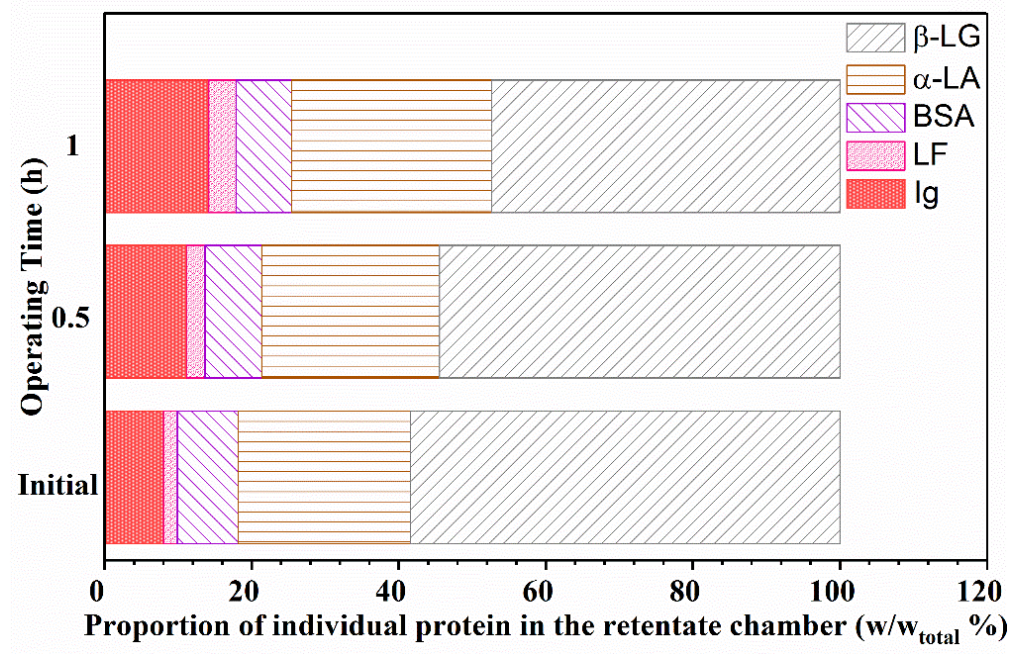

Figure 9 The composition of retentate solution vs operating time using a model whey solution prepared from WPI (feed solution: $40 \mathrm{~mL}$ model whey solution prepared from WPI; 1/4 SMUF (no $\left.\mathrm{Ca}^{2+}, \mathrm{Mg}^{2+}\right), \mathrm{pH}=8$, voltage: $100 \mathrm{~V}(\sim 77 \mathrm{~V} / \mathrm{cm})$, time: $\left.1 \mathrm{~h}\right)$.

The protein loss due to fouling with different buffer solutions was also tested. With a $1 / 4$ SMUF (no $\left.\mathrm{Ca}^{2+}, \mathrm{Mg}^{2+}\right)$ buffer, the loss of alpha-lactalbumin and beta-lactoglobulin over two hours is highest (6.4 \pm 1.3 and $17 \pm 4 \mathrm{~g} / \mathrm{m}^{2}$ respectively, or $12-14 \%$ ) (see Table S-3) due to their smaller size which can readily be accommodated within the membrane structure. The loss of the more valuable LF and Ig is smaller both in absolute and percentage terms (Figure 10 and Table S-3). The process with 4 times diluted SMUF (no $\mathrm{Ca}^{2+}, \mathrm{Mg}^{2+}$ ) buffer results in significantly less loss of $\mathrm{LF}$ compared to the one with 8 times diluted SMUF (no $\mathrm{Ca}^{2+}, \mathrm{Mg}^{2+}$ ). It may be that at the eightfold dilution, the LF may no longer 
be present entirely as tetramers or aggregates, with monomers or dimers penetrating the membrane structure and adsorbing within the porous support. As shown in Figure 10 (a), the washing process can only recover some of the LF that is adsorbed during the use of an eightfold dilution. The Ig loss during both processes is greater than the LF loss both because it is present in the feed solution at a higher concentration and because its lower molecular weight may mean that it can pass through larger pores within the separation membrane and adsorb within the porous support. Again, only a proportion of this Ig can be recovered during a wash step.
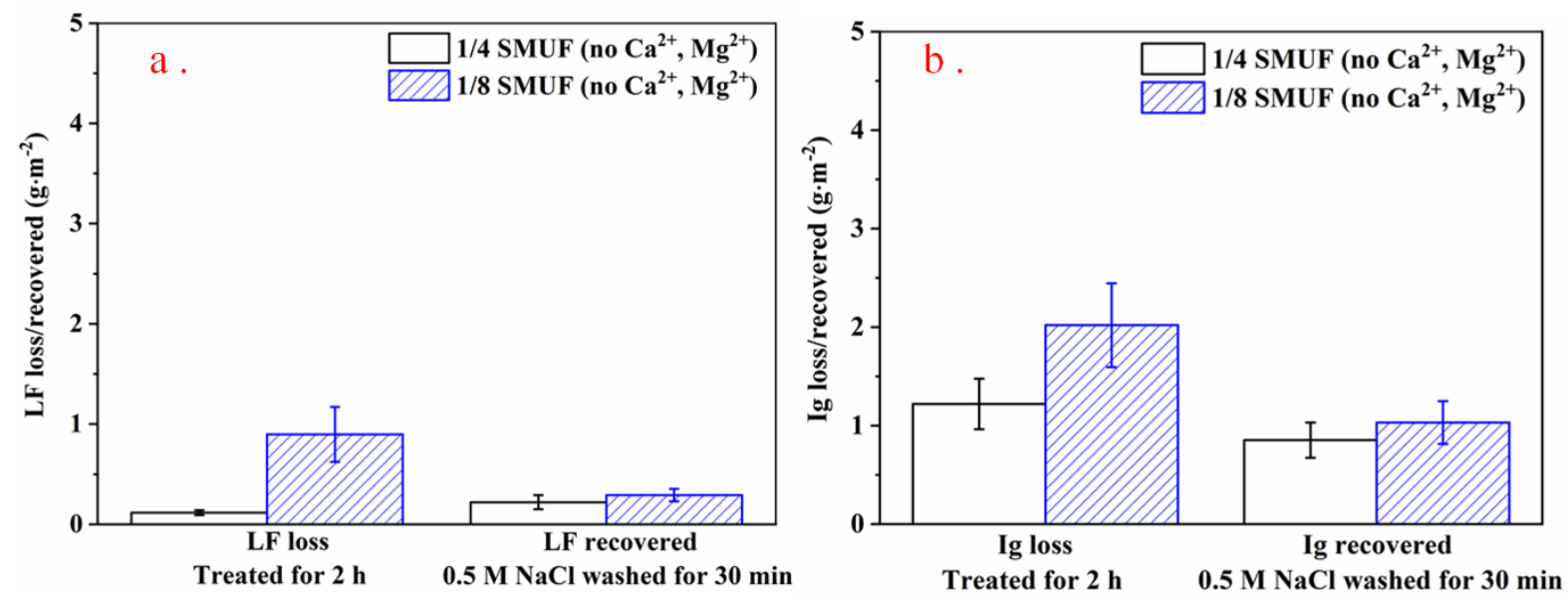

Figure 10 The LF/Ig loss/recovered of processes using a model whey solution prepared from WPI with different buffer solutions. (feed solution: $40 \mathrm{~mL}$ model whey solution prepared from WPI, $\mathrm{pH}=8$, voltage: $100 \mathrm{~V}(\sim 77 \mathrm{~V} / \mathrm{cm})$, time: $2 \mathrm{~h})$.

As aforementioned, using 4 times diluted SMUF (no $\mathrm{Ca}^{2+}, \mathrm{Mg}^{2+}$ ) as buffer solution gives a higher protein transfer rate and lower LF loss, but the energy consumption of this process also should be investigated. Due to its lower ionic concentrations, the feed solution with 1/8 SMUF has less ions transferred (i.e. less current) in the first 30 minutes and thus the energy consumption is lower both in absolute terms (43 versus $67 \mathrm{~W}$ ) and per $\mathrm{kg}$ of protein (BSA, $\alpha$-LA and $\beta-\mathrm{LG}$ ) removed from the retentate chamber (250 versus $345 \mathrm{kWh} / \mathrm{kg}$ ). The range of energy consumption generally observed in EDUF/EDFM is $130 \sim 25000 \mathrm{kWh} / \mathrm{kg}[30,44,45]$, so these results are within the range of other reported EDFM processes. Beyond 30 minutes, the ion concentrations in the retentate chamber decrease for both SMUF concentrations, reducing the current, which leads to a lower absolute energy consumption. However, due to back diffusion of protein from the permeate chamber, the energy consumption per $\mathrm{kg}$ of protein removed increases to an unsustainable level. In an industrial process, a once through mode or changes to the permeate/feed volume ratio would reduce this back diffusion and thus keep the energy demand to a realistic level. 


\section{Conclusion}

The biggest challenge of Ig and lactoferrin fractionation is the separation of BSA and lactoferrin. In the present case, this is achieved by the aggregation of lactoferrin in a salty buffer, such as that available naturally in whey The solution containing the aggregated lactoferrin and other dairy proteins can then be passed through an electrodialysis with ultrafiltration process, where the smaller proteins, characterised here by BSA, can pass through, while the larger LF aggregates and Ig are retained.

In this article, asymmetric PVA filtration membranes prepared by a phase inversion method were used as the ultrafiltration separation method. Chemical crosslinking was used to provide structural resistance. Further, for a process with a negatively charged target protein, this chemical crosslinking method reduced the extent of membrane fouling, by inducing a negative charge. To counteract this, the negative charge induces a small amount of water splitting, which increased energy demand and water transfer.

To achieve a high recovery rate for target proteins, neutral polyacrylaminde membranes were most effective as restriction membranes. Protein loss was also minimised by using a whey solution of lower ionic strength, which can be readily achieved through the partial demineralisation of the whey. Further, a washing process with a simple salt solution was able to recover the residual protein deposit. A partially deionised whey of fourfold reduced total salt concentration and depleted in divalent ions provides a high protein removal rate and low Ig/LF loss. However, the use of a whey with lower salt concentration (diluted eightfold) leads to a lower energy consumption, as fewer ions must be moved. To reduce the energy consumption and to achieve higher product purity, back diffusion of protein must be avoided, by maintaining the permeate protein concentration below that of the feed. In practice, this could possibly be achieved by once through countercurrent operation, or by varying the permeate to feed volume ratio. The process shows good selectivity between $\mathrm{Ig} / \mathrm{LF}$ and other whey proteins.

At this point, the largest feed volume we have tested is only $40 \mathrm{~mL}$ and the effective area of our device is only $15.6 \mathrm{~cm}^{2}$. Further work is required to scale up such a device to investigate if a product with a greater percentage of Ig and LF can be obtained. It is established that EDUF processes are highly effective in separating large molecules with biological activity [30, 46, 62]. Further, the approach uses no solvents or other chemicals that can add to the environmental footprint of the operation [63]. Hence, there is an incentive to further develop the process to make it suitable for the separation/fractionation of charged molecules of large size. 
- AUTHOR INFORMATION

*Corresponding author. Prof. S. E. Kentish, Tel: +61 38344 6682; Fax: +61 38344 6682; E-mail: sandraek@unimelb.edu.au (S. E. Kentish)

\section{- ACKNOWLEDGMENTS}

This work was supported by the Australian Research Council's Industrial Transformation Research Program (ITRP) funding scheme (Project Number IH120100005), Q. Wang acknowledges the University of Melbourne for a Melbourne Research Scholarship. We also acknowledge the generous donation of the EDUF apparatus by Memphasys Ltd. 


\section{References:}

[1] S. Ganju, P.R. Gogate, A review on approaches for efficient recovery of whey proteins from dairy industry effluents, Journal of Food Engineering, 215 (2017) 84-96.

[2] R. Aguero, E. Bringas, M. San Roman, I. Ortiz, R. Ibanez, Membrane Processes for Whey Proteins Separation and Purification. A Review, Current Organic Chemistry, 21 (2017) 1740-1752.

[3] R. Božanić, I. Barukčić, K. Lisak, Possibilities of whey utilisation, Austin Journal of Nutrition and Food Sciences, 2 (2014) 1036.

[4] A. Arunkumar, M.R. Etzel, Fractionation of alpha-lactalbumin and beta-lactoglobulin from bovine milk serum using staged, positively charged, tangential flow ultrafiltration membranes, Journal of Membrane Science, 454 (2014) 488-495.

[5] L. Bazinet, J. Amiot, J.-F. Poulin, D. Labbe, A. Tremblay, Process and system for separation of organic charged compounds, WO 2005/082495A1, (2005).

[6] M.-E. Langevin, C. Roblet, C. Moresoli, C. Ramassamy, L. Bazinet, Comparative application of pressure-and electrically-driven membrane processes for isolation of bioactive peptides from soy protein hydrolysate, Journal of Membrane Science, 403 (2012) 15-24.

[7] N. Lawrence, S. Kentish, A. O'Connor, A. Barber, G. Stevens, Microfiltration of skim milk using polymeric membranes for casein concentrate manufacture, Separation and Purification Technology, 60 (2008) 237-244.

[8] J.-F. Poulin, J. Amiot, L. Bazinet, Simultaneous separation of acid and basic bioactive peptides by electrodialysis with ultrafiltration membrane, Journal of Biotechnology, 123 (2006) 314-328.

[9] J. Margolis, Electrophoretic method for preparative separation of charged molecules in liquids, WO 1988/007406 A1, (1988).

[10] D. Ogle, G. Vigh, D. Rylatt, Multi-port separation apparatus and method, WO 2002/028516 A1, (2002).

[11] D. Ogle, A. Ho, T. Gibson, D. Rylatt, E. Shave, P. Lim, G. Vigh, Preparative-scale isoelectric trapping separations using a modified Gradiflow unit, Journal of Chromatography A, 979 (2002) 155161.

[12] Z.S. Horvath, G.L. Corthals, C.W. Wrigley, J. Margolis, Multifunctional apparatus for electrokinetic processing of proteins, Electrophoresis, 15 (1994) 968-971.

[13] L. Bazinet, J. Amiot, J.-F. POULIN, D. LABBÉ, D. Tremblay, Process and system for separation of organic charged compounds WO 2005/082495 A1, (2005).

[14] M. Aider, S. Brunet, L. Bazinet, Effect of $\mathrm{pH}$ and cell configuration on the selective and specific electrodialytic separation of chitosan oligomers, Separation and Purification Technology, 63 (2008) 612-619.

[15] M. Aider, S. Brunet, L. Bazinet, Electroseparation of chitosan oligomers by electrodialysis with ultrafiltration membrane (EDUF) and impact on electrodialytic parameters, Journal of Membrane Science, 309 (2008) 222-232.

[16] L. Bazinet, Y. DeGrandpré, A. Porter, Electromigration of tobacco polyphenols, Separation and Purification Technology, 41 (2005) 101-107.

[17] D. Labbé, M. Araya-Farias, A. Tremblay, L. Bazinet, Electromigration feasibility of green tea catechins, Journal of Membrane Science, 254 (2005) 101-109.

[18] E. Husson, M. Araya-Farias, Y. Desjardins, L. Bazinet, Selective anthocyanins enrichment of cranberry juice by electrodialysis with ultrafiltration membranes stacked, Innovative Food Science \& Emerging Technologies, 17 (2013) 153-162.

[19] J. Billakanti, Extraction of High-Value Minor Proteins from Milk(Ph.D. dissertation), University of Canterbury (2009).

[20] M.J. Playne, L. Bennett, G. Smithers, Functional dairy foods and ingredients, Australian Journal of Dairy Technology, 58 (2003) 242-264.

[21] B. Van der Strate, L. Beljaars, G. Molema, M. Harmsen, D. Meijer, Antiviral activities of lactoferrin, Antiviral research, 52 (2001) 225-239.

[22] L.H. Vorland, Lactoferrin: a multifunctional glycoprotein, Apmis, 107 (1999) 971-981.

[23] Y.-C. Yoo, S. Watanabe, R. Watanabe, K. Hata, K.-i. Shimazaki, I. Azuma, Bovine Lactoferrin and Lactoferricin TM Inhibit Tumor Metastasis in Mice, in: Advances in Lactoferrin Research, Springer, 1998, pp. 285-291. 
[24] D. Legrand, E. Elass, A. Pierce, J. Mazurier, Lactoferrin and host defence: an overview of its immuno-modulating and anti-inflammatory properties, Biometals, 17 (2004) 225-229.

[25] E.-M. Lilius, P. Marnila, The role of colostral antibodies in prevention of microbial infections, Current Opinion in Infectious Diseases, 14 (2001) 295-300.

[26] V. Valiño, M.F. San Román, R. Ibañez, I. Ortiz, Improved separation of bovine serum albumin and lactoferrin mixtures using charged ultrafiltration membranes, Separation and Purification Technology, 125 (2014) 163-169.

[27] I. Mela, E. Aumaitre, A.-M. Williamson, G.E. Yakubov, Charge reversal by salt-induced aggregation in aqueous lactoferrin solutions, Colloids and Surfaces B: Biointerfaces, 78 (2010) 53-60.

[28] R.M. Bennett, G.C. Bagby, J. Davis, Calcium-dependent polymerization of lactoferrin, Biochemical and Biophysical Research Communications, 101 (1981) 88-95.

[29] R. Jenness, Preparation and properties of a salt solution which simulates milk ultrafiltrate, Netherlands Milk and Dairy Journal, 16 (1962) 153-164.

[30] N. Ndiaye, Y. Pouliot, L. Saucier, L. Beaulieu, L. Bazinet, Electroseparation of bovine lactoferrin from model and whey solutions, Separation and Purification Technology, 74 (2010) 93-99.

[31] H. Nur, M. Van Koeverden, S.E. Kentish, Biocompatible Polymeric Membranes, in: A.P. Office (Ed.), 2017.

[32] B. Bolto, T. Tran, M. Hoang, Z. Xie, Crosslinked poly (vinyl alcohol) membranes, Progress in Polymer Science, 34 (2009) 969-981.

[33] X. Wang, M. Zhou, X. Meng, L. Wang, D. Huang, Effect of protein on PVDF ultrafiltration membrane fouling behavior under different $\mathrm{pH}$ conditions: interface adhesion force and XDLVO theory analysis, Frontiers of Environmental Science \& Engineering, 10 (2016) 12.

[34] Y. Zhang, H. Li, H. Li, R. Li, C. Xiao, Preparation and characterization of modified polyvinyl alcohol ultrafiltration membranes, Desalination, 192 (2006) 214-223.

[35] A. Amanda, S.K. Mallapragada, Comparison of protein fouling on heat-treated poly(vinyl alcohol), poly(ether sulfone) and regenerated cellulose membranes using diffuse reflectance infrared Fourier transform spectroscopy, Biotechnology Progress, 17 (2001) 917-923.

[36] W.Y. Chuang, T.H. Young, W.Y. Chiu, C.Y. Lin, The effect of polymeric additives on the structure and permeability of poly(vinyl alcohol) asymmetric membranes, Polymer, 41 (2000) 56335641.

[37] X. He, C. Chen, Z. Jiang, Y. Su, Computer simulation of formation of polymeric ultrafiltration membrane via immersion precipitation, Journal of Membrane Science, 371 (2011) 108-116.

[38] A. Ahmad, N. Yusuf, B. Ooi, Preparation and modification of poly (vinyl) alcohol membrane: Effect of crosslinking time towards its morphology, Desalination, 287 (2012) 35-40.

[39] M.G. Katz, T. Wydeven Jr, Selective permeability of PVA membranes. II. Heat-treated membranes, Journal of Applied Polymer Science, 27 (1982) 79-87.

[40] H. Bodugoz-Senturk, J. Choi, E. Oral, J.H. Kung, C.E. Macias, G. Braithwaite, O.K. Muratoglu, The effect of polyethylene glycol on the stability of pores in polyvinyl alcohol hydrogels during annealing, Biomaterials, 29 (2008) 141-149.

[41] G. Mukherjee, Modification of poly (vinyl alcohol) for improvement of mechanical strength and moisture resistance, Journal of Materials Science, 40 (2005) 3017-3019.

[42] B. Han, J. Li, C. Chen, C. Xu, S. Wickramasinghe, Effects of degree of formaldehyde acetal treatment and maleic acid crosslinking on solubility and diffusivity of water in PVA membranes, Chemical Engineering Research and Design, 81 (2003) 1385-1392.

[43] G. Bobe, D.C. Beitz, A.E. Freeman, G.L. Lindberg, Separation and quantification of bovine milk proteins by reversed-phase high-performance liquid chromatography, Journal of Agricultural and Food Chemistry, 46 (1998) 458-463.

[44] S. Suwal, C. Roblet, J. Amiot, A. Doyen, L. Beaulieu, J. Legault, L. Bazinet, Recovery of valuable peptides from marine protein hydrolysate by electrodialysis with ultrafiltration membrane: impact of ionic strength, Food Research International, 65 (2014) 407-415.

[45] V.K. Noudou, S. Suwal, J. Amiot, S. Mikhaylin, L. Beaulieu, L. Bazinet, Simultaneous electroseparation of anionic and cationic peptides: Impact of feed peptide concentration on migration rate, selectivity and relative energy consumption, Separation and Purification Technology, 157 (2016) 53-59. 
[46] A. Doyen, C.C. Udenigwe, P.L. Mitchell, A. Marette, R.E. Aluko, L. Bazinet, Anti-diabetic and antihypertensive activities of two flaxseed protein hydrolysate fractions revealed following their simultaneous separation by electrodialysis with ultrafiltration membranes, Food chemistry, 145 (2014) 66-76.

[47] K.P. Palmano, D.F. Elgar, Detection and quantitation of lactoferrin in bovine whey samples by reversed-phase high-performance liquid chromatography on polystyrene-divinylbenzene, Journal of Chromatography A, 947 (2002) 307-311.

[48] J.J. Pesek, M.T. Matyska, J.P. Venkat, Evaluation of protein, peptide, and amino acid retention on C5 hydride-based stationary phases, Journal of Separation Science, 31 (2008) 2560-2566. [49] V. Valiño, M.F. San Román, R. Ibáñez, J.M. Benito, I. Escudero, I. Ortiz, Accurate determination of key surface properties that determine the efficient separation of bovine milk BSA and LF proteins, Separation and Purification Technology, 135 (2014) 145-157.

[50] B. Chaufer, M. Rabiller-Baudry, D. Lucas, F. Michel, M. Timmer, Selective extraction of lysozyme from a mixture with lactoferrin by ultrafiltration. Role of The Physico-chemical Environment, Le Lait, 80 (2000) 197-203.

[51] G. Brisson, M. Britten, Y. Pouliot, Electrically-enhanced crossflow microfiltration for separation of lactoferrin from whey protein mixtures, Journal of Membrane Science, 297 (2007) 206-216.

[52] G. Rice, A.R. Barber, A.J. O'Connor, A. Pihlajamaki, M. Nystrom, G.W. Stevens, S.E. Kentish, The influence of dairy salts on nanofiltration membrane charge, Journal of Food Engineering, 107 (2011) 164-172.

[53] H. Deng, G.Q. Chen, S.L. Gras, S.E. Kentish, The effect of restriction membranes on mass transfer in an electrodialysis with filtration membrane process, Journal of Membrane Science, 526 (2017) 429-436.

[54] R. Simons, Electric field effects on proton transfer between ionizable groups and water in ion exchange membranes, Electrochimica Acta, 29 (1984) 151-158.

[55] P. Długołęcki, B. Anet, S.J. Metz, K. Nijmeijer, M. Wessling, Transport limitations in ion exchange membranes at low salt concentrations, Journal of Membrane Science, 346 (2010) 163-171.

[56] G. Chen, W. Song, B. Qi, J. Li, R. Ghosh, Y. Wan, Separation of protein mixtures by an integrated electro-ultrafiltration-electrodialysis process, Separation and Purification Technology, 147 (2015) 32-43.

[57] H.-J. Lee, H. Strathmann, S.-H. Moon, Determination of the limiting current density in electrodialysis desalination as an empirical function of linear velocity, Desalination, 190 (2006) 4350.

[58] H.-J. Lee, F. Sarfert, H. Strathmann, S.-H. Moon, Designing of an electrodialysis desalination plant, Desalination, 142 (2002) 267-286.

[59] R. Simons, The origin and elimination of water splitting in ion exchange membranes during water demineralisation by electrodialysis, Desalination, 28 (1979) 41-42.

[60] B. Ahmad, M.Z. Kamal, R.H. Khan, Alkali-induced conformational transition in different domains of bovine serum albumin, Protein and Peptide Letters, 11 (2004) 307-315.

[61] M. Turek, Cost effective electrodialytic seawater desalination, Desalination, 153 (2003) 371-376.

[62] R. He, A.T. Girgih, E. Rozoy, L. Bazinet, X.-R. Ju, R.E. Aluko, Selective separation and concentration of antihypertensive peptides from rapeseed protein hydrolysate by electrodialysis with ultrafiltration membranes, Food Chemistry, 197 (2016) 1008-1014.

[63] R. Durand, E. Fraboulet, A. Marette, L. Bazinet, Simultaneous double cationic and anionic molecule separation from herring milt hydrolysate and impact on resulting fraction bioactivities, Separation and Purification Technology, 210 (2019) 431-441. 


\section{Supporting information:}

\section{S1. Composition of Simulated Milk Ultrafiltrate (SMUF) buffer}

The simulated milk ultrafiltrate (SMUF) was prepared as shown in Table 1

Table S1. Compositions of SMUF buffer [29]

\begin{tabular}{|c|c|c|c|c|c|c|c|c|c|c|}
\hline \multirow[b]{2}{*}{ Ingredient } & \multirow[b]{2}{*}{ Weight } & \multicolumn{9}{|c|}{ Composition $(\mathrm{mg} / 100 \mathrm{~mL})$} \\
\hline & & $\mathrm{Na}$ & K & $\mathrm{Ca}$ & $\mathrm{Mg}$ & $\mathrm{P}$ & $\mathrm{Cl}$ & $\begin{array}{l}\text { Citrate as } \\
\text { citrate acid }\end{array}$ & $\mathrm{SO}_{4}$ & $\mathrm{CO}_{2}$ \\
\hline $\mathrm{KH}_{2} \mathrm{PO}_{4}$ & 1.58 & & 45.4 & & & 36.0 & & & & \\
\hline $\mathrm{K}_{3}$ citrate $\cdot \mathrm{H}_{2} \mathrm{O}$ & 1.20 & & 43.4 & & & & & 70.0 & & \\
\hline $\mathrm{Na}_{3}$ citrate $\cdot 5 \mathrm{H}_{2} \mathrm{O}$ & 2.12 & 42.0 & & & & & & 115 & & \\
\hline $\mathrm{K}_{2} \mathrm{SO}_{4}$ & 0.18 & & 8.0 & & & & & & 9.9 & \\
\hline $\mathrm{CaCl}_{2} \cdot 2 \mathrm{H}_{2} \mathrm{O}$ & 1.32 & & & 35.9 & & & 63.8 & & & \\
\hline $\mathrm{MgCl}_{2} \cdot 6 \mathrm{H}_{2} \mathrm{O}$ & 0.65 & & & & 7.8 & & 22.7 & & & \\
\hline $\mathrm{K}_{2} \mathrm{CO}_{3}$ & 0.30 & & 17.0 & & & & & & & 9.5 \\
\hline $\mathrm{KCl}$ & 0.60 & & 31.4 & & & & 28.5 & & & \\
\hline $\mathrm{KOH}$ to $\mathrm{pH} 6.6$ & 2.25 & & 8.0 & & & & & & & \\
\hline \multirow[t]{2}{*}{ Total } & $\mathrm{mg} / 100 \mathrm{~mL}$ & 42.0 & 154.0 & 35.9 & 7.8 & 36.0 & 115.0 & 185.1 & 9.9 & 9.5 \\
\hline & $\mathrm{mM} / \mathrm{L}$ & 18.3 & 39.4 & 9.0 & 3.2 & 11.6 & 32.4 & 9.6 & 1.0 & 2.2 \\
\hline
\end{tabular}

\section{S2. Polyacrylamide Gel Electrophoresis (PAGE)}

Native-PAGE and SDS-PAGE were used to determine the size of native and denatured proteins respectively. All reagents for SDS-Page and Native-Page are purchased from Bio-Rad Laboratories Pty., Ltd (NSW, Australia). For native-page, a Criterion ${ }^{\mathrm{TM}} \mathrm{TGX}^{\mathrm{TM}}$ Precast gel with a gel percentage of $8 \%$ $16 \%$ and 18 wells was used; the running buffer was $10 \times$ Tris/glycine buffer (before dilution: $25 \mathrm{mM}$ Tris, $192 \mathrm{mM}$ glyclne, $\mathrm{pH} 8.3$ ) which was diluted 10 times before use; the sample buffer was $62.5 \mathrm{mM}$ tris- $\mathrm{HCl}, \mathrm{pH} 6.8,40 \%(\mathrm{v} / \mathrm{v})$ glycerol and $0.01 \%$ bromophenol. For SDS-PAGE, a Criterion ${ }^{\mathrm{TM}} \mathrm{TGX}^{\mathrm{TM}}$ Precast gel with a gel percentage of $4 \%-20 \%$ and 18 wells was used; the running buffer was 10×Tris/glycine/SDS buffer (before dilution: $25 \mathrm{mM}$ Tris, $192 \mathrm{mM}$ glyclne, $0.1 \%$ SDS, pH 8.3) which was diluted 10 times before use. The sample buffer was laemmli sample buffer with $65.8 \mathrm{mM}$ tris- $\mathrm{HCl}$, $\mathrm{pH}$ 6.8, 2.1\% SDS, 26.3\%(W/V) glycerol, 0.01 bromophenol, which would mix with loading solution with a ratio of 1:1. For both SDS-PAGE and Native-PAGE, Bio-Safe ${ }^{\mathrm{TM}}$ Coomassie G-250 stain was used. 


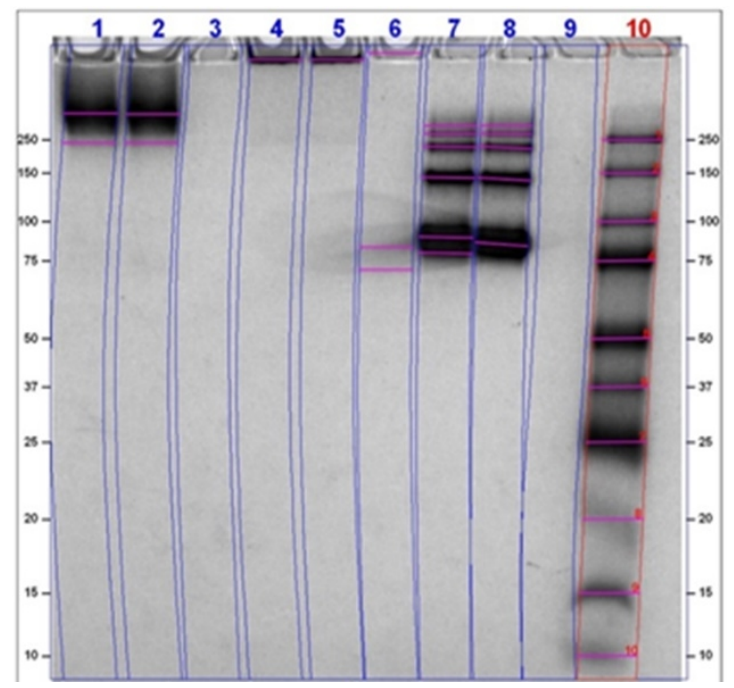

Figure S1 the Native PAGE test result of Ig, LF and BSA (Channels 1 and 2 are for a feed of $1 \mathrm{~g} / \mathrm{L}$ Ig; Channels 4 and 5 are for $1 \mathrm{~g} / \mathrm{L}$ of Lactoferrin, Channels 7 and 8 are for $1 \mathrm{~g} / \mathrm{L}$ of BSA, Channel 10 provides molecular weight standards)

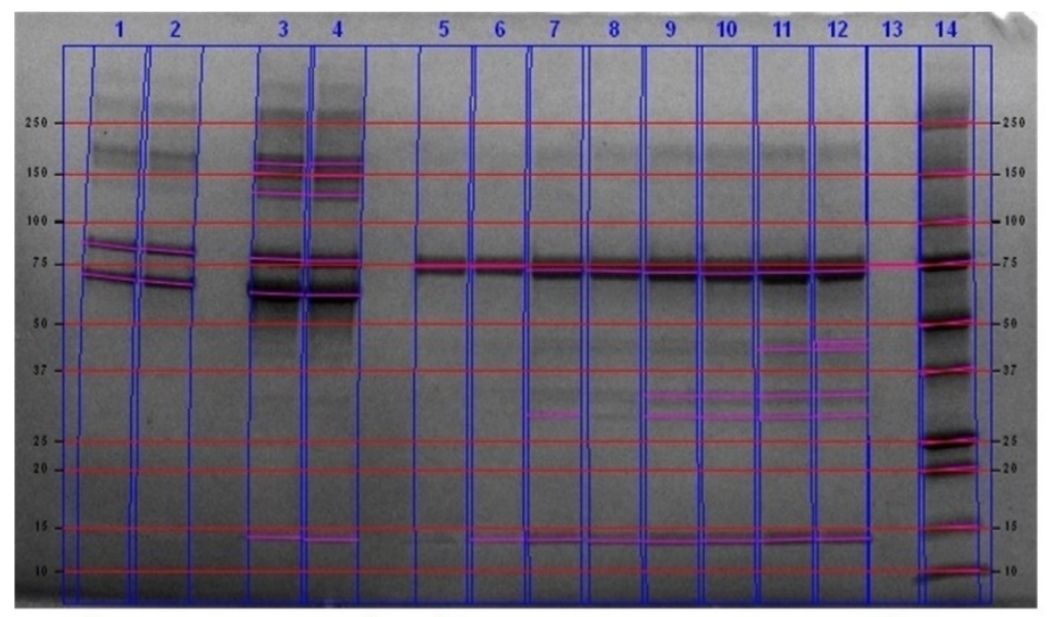

Figure S2 the SDS PAGE test result of LF and BSA (Channels 1 and 2 are for a mixture of $0.1 \mathrm{~g} / \mathrm{L}$ $\mathrm{LF}+0.4 \mathrm{~g} / \mathrm{L}$ BSA; Channels 3 and 4 are for $0.2 \mathrm{~g} / \mathrm{L} \mathrm{LF}+0.8 \mathrm{~g} / \mathrm{L}$ BSA, Channels 5 and 6 are for 0.25 $\mathrm{g} / \mathrm{L}$ of LF, Channels 7 and 8 are for $0.5 \mathrm{~g} / \mathrm{L}$ of LF, Channels 9 and 10 are for $0.75 \mathrm{~g} / \mathrm{L}$ of LF, Channels 11 and 12 are for $1 \mathrm{~g} / \mathrm{L}$ of $\mathrm{LF}$, Channel 14 provides molecular weight standards)

To confirm that the LF is restricted from the Native-PAGE gel by its size, rather than charge, its mobility in a Native PAGE running buffer was investigated using the Malvern Zetasizer NanoZS. As shown in Table S2, although the mobility of lactoferrin is affected by its concentration, it remains negatively charged in the running buffer.

Table S2 the mobility of lactoferrin in the Native PAGE running buffer

\begin{tabular}{ccc}
\hline LF concentration $(\mathrm{g} / \mathrm{L})$ & 1 & 0.1 \\
\hline Mobility $\left.\left(\times 10^{-8} \mathrm{~m}^{2} \mathrm{~V}^{-1} \mathrm{~S}^{-1}\right)\right)$ & $-0.23 \pm 0.06$ & $-0.08 \pm 0.02$ \\
\hline
\end{tabular}




\section{S3. Characterization of PVA uncrosslinked membranes}

The PVA filtration membrane made here is a hydrophilic membrane with a water content of $0.78 \pm 0.01$ (g water/g swollen membrane) and thickness of $170 \pm 3 \mu \mathrm{m}$. Cryo-SEM and BSA/Ig flux tests were performed to understand its structure and pore size.

As shown in Figure S3, the PVA membrane is asymmetric with a skin layer of thickness $\sim 5 \mu \mathrm{m}$. The skin layer is always orientated to the feed side to reduce protein loss.

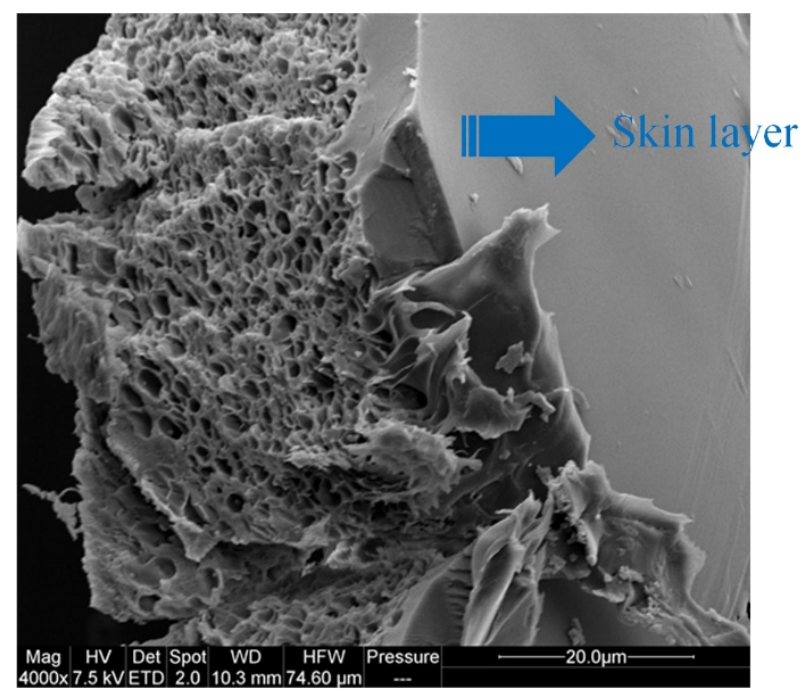

Figure S3 Cryo-SEM image of PVA filtration membrane (80 vol\% of EtOH)

For filtration membranes prepared by phase inversion method, the pore size and structure are affected by the rate of antisolvent diffusion within the coagulation bath. A high concentration of ethanol relative to water corresponds to a rapid phase inversion which can cause a larger pore size but may also lead to shrinkage during the drying process which can make the membrane pore size become smaller. Adding methanol to the coagulation bath can also change the membrane morphology since methanol has a greater diffusion coefficient in water.

Based on our preliminary test, changing the ratio of ethanol and methanol in the coagulation bath while keeping the water content constant (15 vol\%) had little impact on the flux of BSA. However, the flux of the larger Ig protein decreased significantly with a decrease in methanol content. Hence it was decided to focus only on coagulation baths of ethanol/water mixtures.

Increasing the relative proportion of ethanol in the coagulant bath led to a small decline in BSA flux and a more substantial decline in the Ig flux (Figure S4). All of the PVA filtration membranes had a lower flux of Ig than the commercial PAm reference membrane $\left(6.2 \mathrm{~g} \cdot \mathrm{m}^{-2} \cdot \mathrm{h}^{-1}\right)$ but comparable in BSA flux indicating a molecular weight cut-off below $250 \mathrm{kDa}$ but well above that of BSA ( $69 \mathrm{kDa})$. The highest BSA flux is achieved when the proportion of ethanol is $80 \mathrm{vol} \%,\left(33.3 \mathrm{~g} \cdot \mathrm{m}^{-2} \cdot \mathrm{h}^{-1}\right)$ while the greatest selectivity occurs at $85 \mathrm{vol} \%$. The BSA flux $\left(33.1 \mathrm{~g} \cdot \mathrm{m}^{-2} \cdot \mathrm{h}^{-1}\right)$ of this membrane is also higher 
than the value of the reference membrane $\left(31.8 \mathrm{~g} \cdot \mathrm{m}^{-2} \cdot \mathrm{h}^{-1}\right)$. This indicates that a coagulant bath with an ethanol proportion between $80 \%$ and $85 \%$ should provide the best results for this uncrosslinked system.

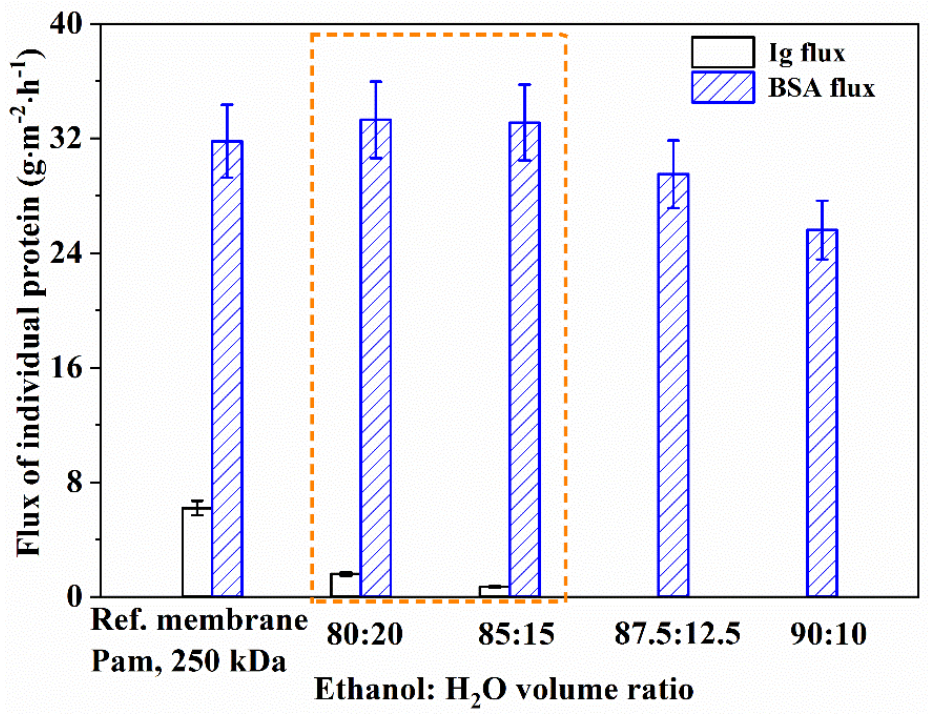

Figure S4 Ig Flux and BSA flux of membranes with different coagulant bath (Ethanol: $\mathrm{H}_{2} \mathrm{O}$ ). (Feed solution: $10 \mathrm{~mL} 3 \mathrm{~g} / \mathrm{L} \mathrm{BSA}$, Tris-base, $\mathrm{pH}=8$, Voltage: $100 \mathrm{~V}$, time: $30 \mathrm{~min}$ )

It should be noted that the BSA flux shown in Figures S4 are approximately three times greater than that shown in Table 1 for an uncrosslinked membrane $\left(11.0 \pm 0.8 \mathrm{~g} \cdot \mathrm{m}^{-2} \cdot \mathrm{h}^{-1}\right)$ because these experiments used a feed solution with a threefold higher BSA concentration ( 3 versus $1 \mathrm{mg} / \mathrm{mL}$ ). 


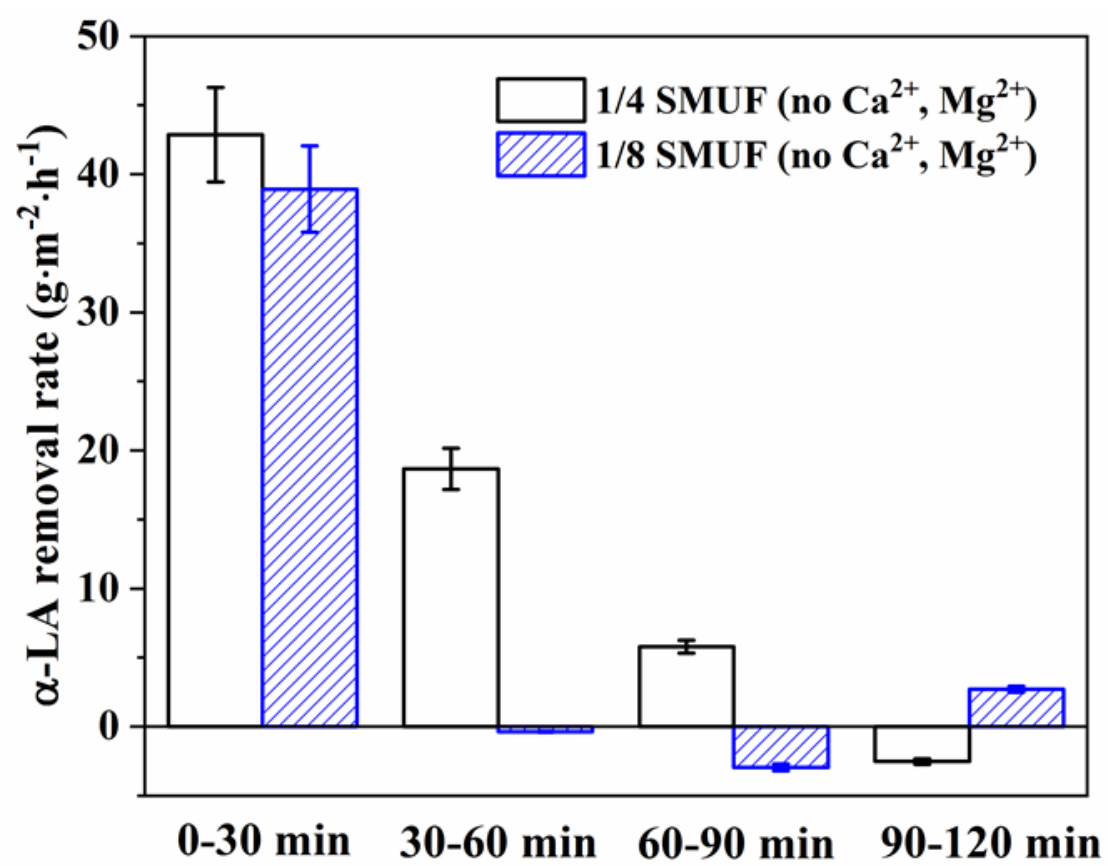

Figure S5 The removal rate of $\alpha$-LA from the feed solution vs time when treating WPI solution in different buffer solutions

(feed solution: $40 \mathrm{~mL}$ model whey solution prepared from WPI, $\mathrm{pH}=8,100 \mathrm{~V}(\sim 77 \mathrm{~V} / \mathrm{cm}), 2 \mathrm{~h}$ )

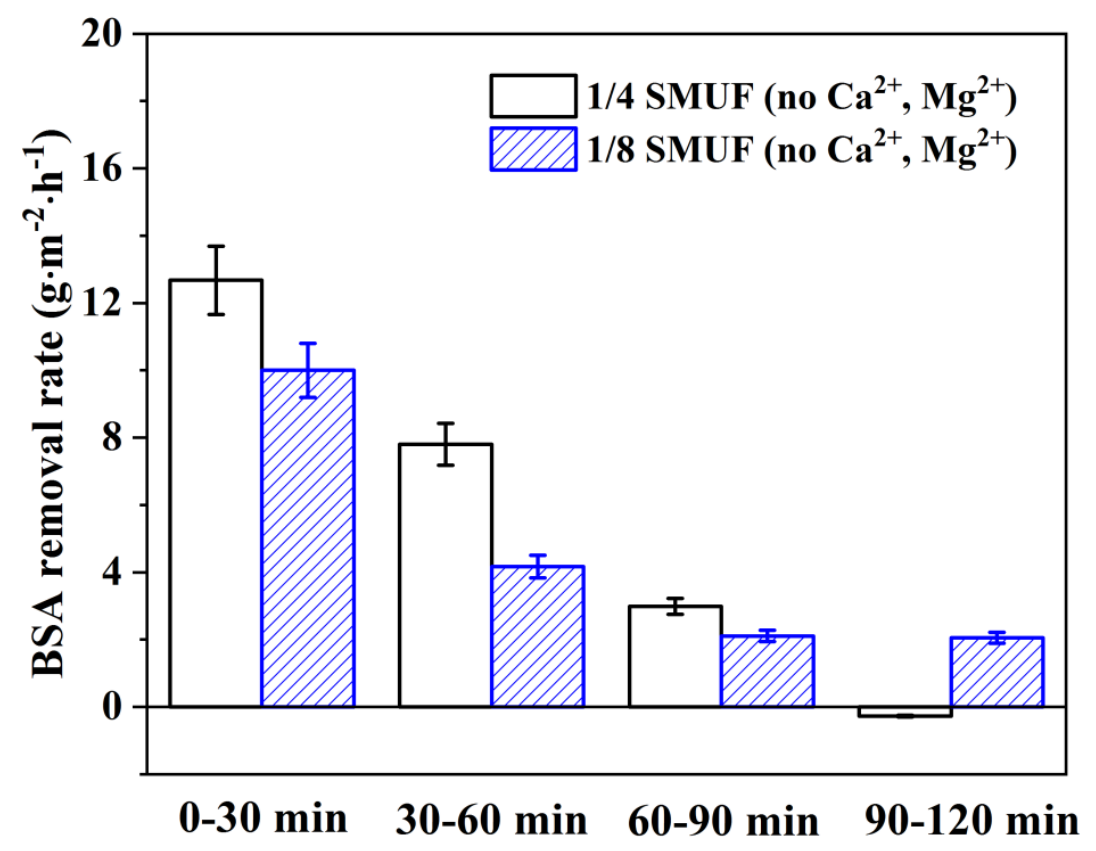

Figure S6 The removal rate of BSA from the feed solution vs time when treating WPI solution in different buffer solutions

(feed solution: $40 \mathrm{~mL}$ model whey solution prepared from WPI, $\mathrm{pH}=8,100 \mathrm{~V}(\sim 77 \mathrm{~V} / \mathrm{cm}), 2 \mathrm{~h})$ 


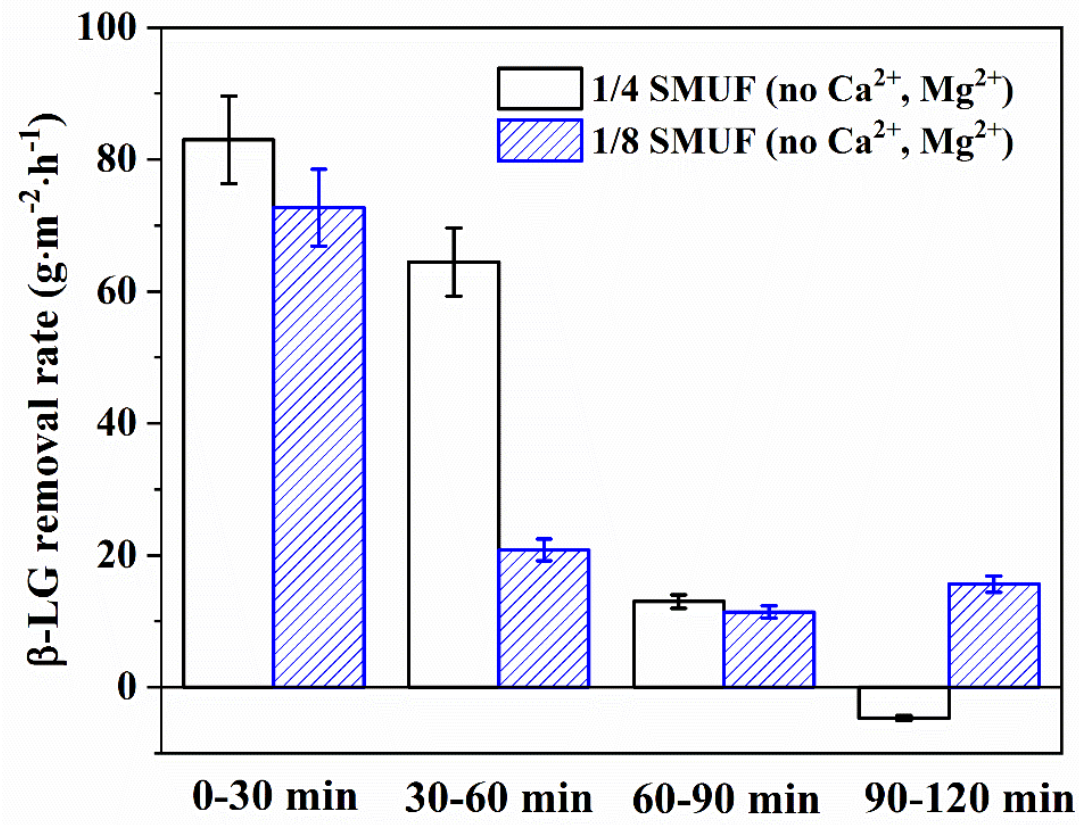

Figure S7 The removal rate of $\beta$-LG from the feed solution vs time when treating WPI solution in different buffer solutions

(feed solution: $40 \mathrm{~mL}$ model whey solution prepared from WPI, $\mathrm{pH}=8,100 \mathrm{~V}(\sim 77 \mathrm{~V} / \mathrm{cm}), 2 \mathrm{~h}$ )

Table S3 The protein loss during EDFM using a model whey solution prepared from WPI with $1 / 4$ SMUF no $\mathrm{Ca}^{2+}$ and $\mathrm{Mg}^{2+}$. Also shown is the amount recovered using a salt water wash (feed solution: $40 \mathrm{~mL}$ model whey solution prepared from WPI, $\mathrm{pH}=8$, voltage: $100 \mathrm{~V}$, time: $2 \mathrm{~h}$ ).

\begin{tabular}{|c|c|c|c|}
\hline \multirow[t]{2}{*}{ Proteins } & \multicolumn{2}{|c|}{ Loss } & \multirow{2}{*}{$\begin{array}{c}\text { Recovered } \\
\mathrm{g} / \mathrm{m}^{2}\end{array}$} \\
\hline & $\mathrm{g} / \mathrm{m}^{2}$ & Loss $\%$ & \\
\hline $\operatorname{Ig}$ & $1.2 \pm 0.3$ & $7.5 \pm 1.6$ & $0.85 \pm 0.2$ \\
\hline LF & $0.11 \pm 0.03$ & $3.1 \pm 0.7$ & $0.22 \pm 0.07$ \\
\hline BSA & $1.6 \pm 0.3$ & $10 \pm 2.1$ & $1.0 \pm 0.2$ \\
\hline$\alpha-\mathrm{LA}$ & $6.4 \pm 1.3$ & $12 \pm 2.5$ & $1.9 \pm 0.4$ \\
\hline$\beta-\mathrm{LG}$ & $17 \pm 4$ & $14 \pm 3$ & $11.5 \pm 2.4$ \\
\hline
\end{tabular}

